\title{
Mortality and reduced photosynthetic performance in sugar kelp Saccharina latissima caused by the salmon-lice therapeutant hydrogen peroxide
}

\author{
Barbro T. Haugland*, Samuel P. S. Rastrick, Ann-Lisbeth Agnalt, Vivian Husa, \\ Tina Kutti, Ole B. Samuelsen
}

Institute of Marine Research, 5005 Bergen, Norway

\begin{abstract}
Sugar kelp Saccharina latissima is one of the dominating kelp species on sheltered sublittoral sites along the Norwegian coastline, providing important habitats and ecosystem services. In finfish aquaculture in Norway, infections caused by salmon lice Lepeophtheirus salmonis are one of the biggest challenges the industry is currently facing, and presently the most-used therapeutant is hydrogen peroxide $\left(\mathrm{H}_{2} \mathrm{O}_{2}\right)$. Commonly, this treatment involves bathing the fish in a solution of approximately $1700 \mathrm{mg} \mathrm{H}_{2} \mathrm{O}_{2} \mathrm{l}^{-1}$ seawater before releasing the solution into the surrounding waters. The present study was conducted to increase the knowledge on how these $\mathrm{H}_{2} \mathrm{O}_{2}$ emissions from farm operations could impact juvenile $S$. latissima. This was achieved by determining the effects of a $1 \mathrm{~h}$ exposure to realistic $\mathrm{H}_{2} \mathrm{O}_{2}$ levels on $S$. latissima mortality and photosynthesis. Effects on photosynthesis were determined by incubating plants at 3 time intervals postexposure. Toxicity potentials including lethal concentration for $50 \%$ of the population $\left(\mathrm{LC}_{50}\right)$ and effective concentration $\left(\mathrm{EC}_{50}\right)$ for photosynthetic capacity $\left(P_{\mathrm{MAX}}\right)$ and efficiency $(\alpha)$ were determined based on these data. Juvenile $S$. latissima was highly sensitive, having an $\mathrm{LC}_{50}$ of $80.7 \mathrm{mg}$ $\mathrm{H}_{2} \mathrm{O}_{2} \mathrm{l}^{-1}$, which is less than $5 \%$ of the dose commonly used at farms and emitted to the environment. A concentration of $85 \mathrm{mg} \mathrm{l}^{-1}$ caused an immediate $90 \%$ reduction in both $P_{\mathrm{MAX}}$ and $\alpha$. The $\mathrm{EC}_{50}$ was found to be 27.8 and $35.4 \mathrm{mg} \mathrm{l}^{-1}$ for $P_{\mathrm{MAX}}$ and $\alpha$, respectively. This may indicate that natural $S$. latissima populations in the vicinity of fish farms can be negatively affected by $\mathrm{H}_{2} \mathrm{O}_{2}$ bath treatments.
\end{abstract}

KEY WORDS: Kelp mortality $\cdot$ Kelp photosynthesis · Aquaculture effluents

\section{INTRODUCTION}

Production of salmonid fish is a major industry in Norway, with $>1.3$ million tons produced in 2016, a 3 -fold increase over the last $15 \mathrm{yr}$ (Directorate of Fisheries Norway 2018b). Fish in the high-density conditions of modern aquaculture are susceptible to bacterial, viral, and parasitic diseases. At present, infestation with salmon lice Lepeophtheirus salmonis is a major problem for the Norwegian fish-farming industry, increasing the requirement for effective antiparasitic therapeutants. Several antiparasitic thera-

*Corresponding author: bthaugland@hi.no peutants are currently in use to mitigate the effects of sea lice on cultured Atlantic salmon (Grefsrud et al. 2018). These are administered as a bath treatment or orally via feed and are ultimately released into the environment. Recent studies have shown that the release of these chemical therapeutants can have significant consequences for non-target organisms in marine ecosystems (e.g. Samuelsen et al. 2014, Van Geest et al. 2014).

Hydrogen peroxide $\left(\mathrm{H}_{2} \mathrm{O}_{2}\right)$ is used in salmonid aquaculture in Norway, as well as in Chile, Canada, and Scotland (Burridge et al. 2010). $\mathrm{H}_{2} \mathrm{O}_{2}$ is adminis-

() The authors 2019. Open Access under Creative Commons by Attribution Licence. Use, distribution and reproduction are unrestricted. Authors and original publication must be credited. 
tered as a 15-20 min bath treatment of approximately 1500-2100 mg $\mathrm{H}_{2} \mathrm{O}_{2} \mathrm{l}^{-1}$, depending on water temperature (www.felleskatalogen.no). This is conducted either at the farm by wrapping a tarpaulin around the net pen or using a well-boat (Andersen \& Hagen 2016). After treatment, the tarpaulin is removed, and the $\mathrm{H}_{2} \mathrm{O}_{2}$ disperses into the surrounding water or is pumped out from the well-boat directly into the sea. $\mathrm{H}_{2} \mathrm{O}_{2}$ dissociates into oxygen and water, and is therefore seen as being 'environmentally friendly' (Burridge et al. 2010), and $\mathrm{H}_{2} \mathrm{O}_{2}$ emissions are currently not included in any environmental risk assessments in relation to fish-farm activities. However, the half-life is approximately $7 \mathrm{~d}$ at $15^{\circ} \mathrm{C}$ and longer at colder temperatures (Bruno \& Raynard 1994), leaving a window of time where this highly reactive oxidizer may interact with non-target species. As the $\mathrm{H}_{2} \mathrm{O}_{2}$ solution has similar density to the surrounding seawater, the effluent plume is likely to be concentrated in the upper $\sim 30 \mathrm{~m}$ of the water column (Andersen \& Hagen 2016, Refseth et al. 2017), making subtidal zones the most likely to be affected. In Norway, $\mathrm{H}_{2} \mathrm{O}_{2}$ is currently the most-used antiparasitic therapeutant, with an annual consumption of 31577,43246 , and 26597 t respectively for the years 2014-2016 (www.fhi.no). Nonetheless, more knowledge regarding potential environmental effects is required to decide if and how these $\mathrm{H}_{2} \mathrm{O}_{2}$ emissions should be included in future environmental risk assessments.

To be able to make inferences regarding the potential effects $\mathrm{H}_{2} \mathrm{O}_{2}$ emissions from fish farms may have on population levels of subtidal species, it is necessary to have knowledge of the toxicity potentials toward non-target species, as well as which doses these species may be exposed to in the natural environment. Two field studies (Andersen \& Hagen 2016, Fagereng 2016) and 2 dispersion models (Refseth et al. 2017, O. Samuelsen unpubl. data) have looked at how the $\mathrm{H}_{2} \mathrm{O}_{2}$ plume may disperse postemission under conditions found in Norwegian waters. Results from the field studies give a snapshot of the concentrations in very close vicinity $(\leq 60 \mathrm{~m})$ to the release point, whereas the dispersion models give indications of how the plume may move locally through time and space. For sheltered locations within $1 \mathrm{~km}$ of the emitting farm, it is predicted that remaining concentrations $24 \mathrm{~h}$ postemission will range from $18 \%$ to $<1 \%$ of the $\mathrm{H}_{2} \mathrm{O}_{2}$ bath-treatment dose used (Refseth et al. 2017, O. Samuelsen unpubl. data). The toxicity potential of these concentrations on subtidal species has not been assessed to date.
Along the Norwegian coastline, one of the most dominating macroalgal habitats are kelp (order Laminariales) forests, estimated to cover an area $>10000 \mathrm{~km}^{2}$, from the shore down to a depth of 20-30 m (Christie et al. 2009). Macroalgae are important primary producers on the continental shelf (Charpy-Roubaud \& Sournia 1990) and key components in coastal ecosystems (Araújo et al. 2016). On sheltered and medium-exposed locations, the sublittoral vegetation is commonly dominated by the perennial sugar kelp Saccharina latissima (Linnaeus) C. E. Lane, C. Mayes, Druehl, \& G. W. Saunders (Andersen et al. 2011, Moy \& Christie 2012). Kelp forests are biodiversity hotspots, serving key functions in the ecosystem by providing refuge, habitat, nursery grounds, and feeding grounds for $>100$ marine faunal species (Christie et al. 2003, 2009, Fredriksen 2003), including economically important fish such as Atlantic cod Gadus morhua and saithe Pollachius virens (Norderhaug et al. 2005), and seabirds such as sea ducks, cormorants, and black guillemots Cepphus grylle (Bustnes et al. 1997).

Healthy photosynthetic activity is essential for algae both in terms of nutritional uptake and in maintaining a positive carbon budget. As in all living cells, $\mathrm{H}_{2} \mathrm{O}_{2}$ and other oxygen intermediates (superoxide radical, singlet oxygen, and hydroxyl radical) are produced in low rates in algae as metabolic by-products and commonly grouped as reactive oxygen species (ROS) (Bischof \& Rautenberger 2012). Algae have antioxidative systems that scavenge ROS, but stress (e.g. suboptimal temperature or light conditions) may cause an imbalance between the accumulation of ROS and the system's antioxidative capacity, leading to oxidative stress (Bischof \& Rautenberger 2012). This in turn may lead to oxidation of cellular components (lipids, nucleic acids, and proteins) and thus damage the photosynthetic apparatus and lead to photoinhibition (Asada \& Takahashi 1987). Concentrations as low as $2 \mathrm{mg} \mathrm{H}_{2} \mathrm{O}_{2} \mathrm{l}^{-1}$ within chloroplasts have shown to cause a $90 \%$ reduction of photosynthetic activity (Kaiser 1979). As $\mathrm{H}_{2} \mathrm{O}_{2}$ has the ability to readily diffuse across membranes (Apostol et al. 1989), exogeneous exposure could therefore have detrimental effects on macroalgae.

High interspecific sensitivity of the photosynthetic system to $\mathrm{H}_{2} \mathrm{O}_{2}$ has been reported both for macroalgae (Collén \& Pedersén 1996, Collén \& Davison 1999) and within the Laminariaceae family (Dummermuth et al. 2003), but $\mathrm{H}_{2} \mathrm{O}_{2}$ sensitivity of $S$. latissima has not been assessed to date. The lethal effectdose of $\mathrm{H}_{2} \mathrm{O}_{2}$ has been determined for one macroalgae (Collén \& Pedersén 1996). For microalgae, 
$\mathrm{H}_{2} \mathrm{O}_{2}$ has previously been evaluated as a growth inhibitor related to nuisance blooms (European Communities 2003 and references therein, Southard 2005). However, studies reporting on toxicity potentials required for environmental risk assessmentssuch as lethal concentration for $50 \%$ of the population $\left(\mathrm{LC}_{50}\right)$, no-effect concentration (NEC), or effective concentration affecting photosynthesis in $50 \%$ of the population $\left(\mathrm{EC}_{50}\right)$ - of $\mathrm{H}_{2} \mathrm{O}_{2}$ on macroalgae, in terms of concentrations and durations comparable to emissions from aquaculture, are lacking.

Reversible and irreversible damage to the photosynthetic apparatus caused by a stressor, such as photosynthetic toxicity potential of $\mathrm{H}_{2} \mathrm{O}_{2}$, can be observed by measuring different photosynthetic parameters. The algae's ability to utilize available light for carbon fixation (photosynthetic efficiency) and the maximum potential rate of carbon fixation (photosynthetic capacity) can be reduced during suboptimal temperature (Davison et al. 1991, Andersen et al. 2013) and light conditions (Borum et al. 2002). Use of fixated carbon (respiration) however, tends to increase, as shown for both temperature (Davison et al. 1991, Andersen et al. 2013) and light (Borum et al. 2002). A reduced photosynthetic efficiency and/ or increased respiration will result in an increase in the minimum amount of light required to maintain a balanced carbon budget (compensation irradiance) and could thus reduce the amount of carbon available for growth (Davison et al. 1991). A lower photosynthetic capacity and/or efficiency will reduce the saturation irradiance of the algae (Davison et al. 1991, Andersen et al. 2013) and could consequently affect their ability to take advantage of high light conditions. Exogeneous exposure to $\mathrm{H}_{2} \mathrm{O}_{2}$ has been shown to reduce photosynthetic efficiency (Collén \& Pedersén 1996, Collén \& Davison 1999, Dummermuth et al. 2003, Vega et al. 2006), while respiration is less sensitive (Collén \& Pedersén 1996, Vega et al. 2006). The effects of exogeneous exposure on photosynthetic capacity, saturation, or compensation depth have, however, not been assessed to date for macroalgae.

Aquaculture is projected to expand dramatically in the near future, and thorough risk assessments which include all potential impacts associated with the industry are essential to maintain healthy coastal ecosystems. Furthermore, S. latissima has been proposed as an excellent species for integrated multitrophic aquaculture (IMTA) in cold-temperate waters (e.g. Petrell et al. 1993, Barrington et al. 2009, Handå et al. 2013), and the best practices for cultivation integrated with salmonid farming are currently being intensely investigated in Norway (reviewed in Stévant et al. 2017). Mortality of $S$. latissima cultivated at fish farms has been observed, and coinciding $\mathrm{H}_{2} \mathrm{O}_{2}$ treatments may have been a possible factor (B. T. Haugland et al. unpubl. data).

Consequently, the aim of the present study was to evaluate the toxicity of $\mathrm{H}_{2} \mathrm{O}_{2}$ on $S$. latissima, mainly to (1) determine potential risks associated with emissions for natural $S$. latissima populations, and, additionally, to (2) determine if treatment with $\mathrm{H}_{2} \mathrm{O}_{2}$ at IMTA farms is innocuous to cultivated $S$. latissima. To achieve this, the toxicity potential of a $1 \mathrm{~h}$ exposure to ecologically relevant levels of $\mathrm{H}_{2} \mathrm{O}_{2}$ on mortality and photosynthetic activity of juvenile $S$. latissima was assessed at 3 time points post-exposure. Novel to effects of $\mathrm{H}_{2} \mathrm{O}_{2}$ exposure on macroalgae, photosynthetic capacity, compensation depth, and saturating irradiance were assessed, in addition to photosynthetic efficiency and dark respiration. $\mathrm{LC}_{50}, \mathrm{EC}_{50}$ and NEC values were also determined.

\section{MATERIALS AND METHODS}

\subsection{Collection and experimental design}

First-year sugar kelp Saccharina latissima was collected by free-diving in the upper subtidal zone (1$3 \mathrm{~m}$ depth) at Hjellestad, SW of Bergen, Norway $\left(60^{\circ} 15^{\prime} 40.4^{\prime \prime} \mathrm{N}, 5^{\circ} 12^{\prime} 31.7^{\prime \prime} \mathrm{E}\right)$ in March 2017 and transported to the Institute of Marine Research, Bergen, in dark plastic bags to avoid exposing the plants to high irradiances (after Dummermuth et al. 2003). Prior to initiation of the experiment, plants were kept at their collection temperature of $8^{\circ} \mathrm{C}$ in $15 \mathrm{l}$ aquariums for minimum $24 \mathrm{~h}$. Six fluorescent daylight lamps (OSRAM L 58W/954) provided irradiance of approximately $100 \mu \mathrm{mol}$ photons $\mathrm{m}^{-2} \mathrm{~s}^{-1}$ (photosynthetically active radiation, PAR) at a natural seasonal regime of $12 \mathrm{~h}$ light: $12 \mathrm{~h}$ dark. A submersible micropump (flow rate: $150 \mathrm{l} \mathrm{h}^{-1}$ ) maintained circulation of the water. Seawater in the aquarium was changed every other day, and no growth medium was added.

A preliminary study was conducted to define the dose-response relationship between $\mathrm{H}_{2} \mathrm{O}_{2}$ concentrations and lethal effects on S. latissima, ranging from $100 \%$ mortality to no effect (see Appendix). In addition to identifying the concentrations to be applied in the main experiment, the preliminary study also indicated that $\mathrm{H}_{2} \mathrm{O}_{2}$ affected the lamina tissue in patches, and not uniformly across the whole lamina. Whole-plant exposure and incubation (after 
Andersen et al. 2013) was therefore chosen over lamina-disc incubation to better simulate how S. latissima plants would be impacted in nature in terms of exposure effects, post-exposure effects, and survival.

Consequently, following lab acclimatization, 5 healthy plants without wounds or fouling were chosen, numbered individually, measured by volume, and randomly assigned to 1 of $5 \mathrm{H}_{2} \mathrm{O}_{2}$ exposure concentrations: $170 \mathrm{mg} \mathrm{l}^{-1}$ (10\% of the bath-treatment dose), $85 \mathrm{mg} \mathrm{l}^{-1}(5 \%), 17 \mathrm{mg} \mathrm{l}^{-1}(1 \%), 1.7 \mathrm{mg} \mathrm{l}^{-1}(0.1 \%)$, or a seawater control (i.e. no $\mathrm{H}_{2} \mathrm{O}_{2}$ ). These concentrations were based on our preliminary dose-response study (see Appendix) and ranged from $10 \%$ to $0.1 \%$ of the bath-treatment dose of $1700 \mathrm{mg} \mathrm{H}_{2} \mathrm{O}_{2} \mathrm{l}^{-1}$ recommended by the producer (www.felleskataloge.no) for a temperature of $8^{\circ} \mathrm{C}$. Plants were exposed in individual 21 beakers for $1 \mathrm{~h}$ under low (50 PAR) light conditions. A total of 30 plants were included in the main study and divided equally between the $5 \mathrm{H}_{2} \mathrm{O}_{2}$ concentrations (i.e. 6 replicate plants per concentration). A randomized schedule was prepared a priori to eliminate potential day effects and incubation chamber effects in the dataset. Following $\mathrm{H}_{2} \mathrm{O}_{2}$ exposure, plants were flushed with fresh seawater for a couple of minutes to remove any $\mathrm{H}_{2} \mathrm{O}_{2}$ on the surface before being transferred to individual incubation chambers per the randomized schedule. Exposures and incubations immediately after exposure were conducted over 9 consecutive days, as 5 plants were exposed at a time. As the preliminary study indicated that effects may not be apparent until several hours postexposure, incubations to determine the effects on photosynthesis were conducted at 3 post-exposure time points: immediately after exposure (Day 0), $24 \mathrm{~h}$ post-exposure (Day 1), and $15 \mathrm{~d}$ post-exposure (Day 15), giving a total of 90 individual incubations.

\subsection{Mortality}

Determining time of mortality in macroalgae is challenging, and to date there are no standardized methods. From the preliminary study, it was found that it is essential to keep the plants in the laboratory for at least $7 \mathrm{~d}$ post-exposure to be able to determine mortality with certainty (see Appendix). The endpoint 'mortality' was determined to be when the lamina disintegrated and/or detached from the stipe when the plant was lifted out of the aquarium by the holdfast. In the main study, each individual was inspected daily and pictures were taken at the end of the $15 \mathrm{~d}$ post-exposure period or when the lamina showed visible signs of disintegration.

\subsection{Effects on photosynthesis}

To assess effects on photosynthetic activity (photosynthetic efficiency, $\alpha$; photosynthetic capacity, $P_{\text {MAX }}$ dark respiration, $R_{\mathrm{D}}$ i compensation irradiance, $I_{\mathrm{C}}$ and saturating light intensity, $\left.I_{\mathrm{SAT}}\right)$, the methodology of Gerard (1988), Henley \& Dunton (1997), and Andersen et al. (2013) was followed. Plants were incubated to construct a photosynthesis-irradiance (PI) curve based on measured oxygen $\left(\mathrm{O}_{2}\right)$ production or consumption over 11 different light intensities (0-350 PAR), starting with $R_{\mathrm{D}}$ (Table 1 ).

Incubations were conducted in $600 \mathrm{ml}$ transparent, gas-tight, rectangular prisms (width: $5 \mathrm{~cm}$, length: $15 \mathrm{~cm}$, height: $15 \mathrm{~cm}$ ) using magnetic stirring for water circulation. The magnetic stirrers were set to the same level (1250 rpm) to ensure the boundary layers around the thallus would be similar for all plants. Filtered seawater (glass-fibre filter, $1 \mu \mathrm{m}$ ) was bubbled with $\mathrm{N}_{2}$ gas to $\sim 60 \%$ air saturation to prevent oversaturation of $\mathrm{O}_{2}$ in the chambers during incubation. One thallus was hung within each incubation chamber from the lid. The incubation chambers were separated by partitions and illuminated directly from the front by one LED lamp (V-Light E14 dimmable HALED bulb; $230 \mathrm{~V}, 7 \mathrm{~W}$ ). The rectangular shape of the chambers allowed for the thallus to be fixed in a perpendicular position to the light source

Table 1. Light levels used to generate photosynthesisirradiance curves for juvenile Saccharina latissima. Values presented are the range (min. to max.) of measured light intensity, and time held, at each light level. $\alpha$ : photosynthetic efficiency, $I_{\mathrm{C}}$ : compensation irradiance, PAR: photosynthetically active radiation, $P_{\mathrm{MAX}}$ : photosynthetic capacity, $R_{\mathrm{D}}$ : dark respiration

\begin{tabular}{|lcc|}
\hline Light level & $\begin{array}{c}\text { Light intensity } \\
\left(\mathrm{PAR}, \mu \text { mol photons } \mathrm{m}^{-2} \mathrm{~s}^{-1}\right)\end{array}$ & $\begin{array}{c}\text { Time interval } \\
(\mathrm{min})\end{array}$ \\
\hline $0^{\mathrm{a}}\left(R_{\mathrm{D}}\right)$ & 0 & 120 \\
$1^{\mathrm{a}}$ & $10-12$ & 30 \\
$2^{\mathrm{a}}$ & $19-22$ & 30 \\
$3^{\mathrm{a}}$ & $29-32$ & 30 \\
$4^{\mathrm{a}}$ & $42-45$ & 30 \\
5 & $64-66$ & 20 \\
6 & $84-88$ & 20 \\
7 & $125-128$ & 10 \\
8 & $146-150$ & 10 \\
$9^{\mathrm{b}}$ & $169-174$ & 10 \\
$10^{\mathrm{b}}$ & $230-235$ & 8 \\
$11^{\mathrm{b}}$ & $347-350$ & 8 \\
${ }^{\mathrm{a} B e l o w}$-saturating light levels used for mixed linear \\
regression to determine $\alpha$ and $I_{\mathrm{C}}$ \\
${ }^{\mathrm{b}}$ Above-saturating light levels used to determine $P_{\mathrm{MAx}}$ \\
\multicolumn{2}{|c}{} \\
\hline
\end{tabular}


throughout the incubation, independently of the water circulation.

The 11 different light levels (Table 1) were attained using a dimmer and density screens while measuring the PAR at every light level. Using separate light sources for each chamber increased control and allowed for adjustments to be made during incubations to ensure that all chambers were exposed to the same amount of irradiance at the different light levels for every incubation. Irradiance was measured as the maximum PAR hitting the front of the chamber at the centre point of the lamina. PAR was measured with a LI-190R quantum cosine-corrected sensor (up to $82^{\circ}$ angle of incidence) coupled to a LI-250A light meter (LI-COR).

At each light level, changes in $\mathrm{O}_{2}$ within the incubation chamber were determined using an optical non-invasive methodology (modified from Rastrick \& Whiteley 2011). Each incubation chamber was internally equipped with an $\mathrm{O}_{2}$ sensor spot and aligned with an exterior fibre optic sensor probe connected to a PreSens ${ }^{\circledR}$ OXY-10 mini sensor. OXY-10 software converted fluorescent readings to changes in seawater $\mathrm{O}_{2}$ levels, and logged the values every $15 \mathrm{~s}$. The plants were therefore held at each light level for $a$ priori set time intervals (determined from test runs) until a $\sim 5 \%$ change in $\mathrm{O}_{2}$ was observed (Table 1), ensuring that all individuals were exposed to the same conditions. For all incubations, 1 control chamber was kept empty, from which the temperature was recorded (LabQuest ${ }^{\circledR} 2$ multimeter, Vernier) and logged every 15 s. Relative humidity (RH \%), barometric pressure $(\mathrm{kPa})$, and salinity were also recorded for each incubation (LabQuest ${ } 2$ multimeter and Logger Lite software, Vernier). Immediately after incubation, the plants were blotted, weighed (fresh weight; FW), and transferred back to the aquarium.

\subsection{Data processing}

To obtain the rate of $\mathrm{O}_{2}$ production or consumption for each light level, the following calculations were conducted. $\mathrm{O}_{2}$ concentration $\left(\mu \mathrm{mol} \mathrm{O}_{2}\right.$ ) over time in the incubation chambers was calculated from $\% \mathrm{O}_{2}$ values transformed to $\mathrm{pO}_{2}$ using measured barometric pressure (adjusted for vapour pressure and relative humidity), multiplied by the solubility coefficients (after Benson \& Krause 1980, 1984, adjusted for temperature and salinity) and the volume of seawater within each incubation chamber (adjusted for the volume of the sample). The values from incubation chambers containing a sample were then corrected for changes in the control chamber. FWstandardized rate of $\mathrm{O}_{2}$ consumption or production at each light level was calculated from the linear regression of $\mathrm{O}_{2}$ concentration $\left(\mu \mathrm{mol} \mathrm{O}_{2}\right.$ ) against time (h) divided by the FW of samples, giving rates expressed in $\mu \mathrm{mol} \mathrm{O}_{2} \mathrm{gFW}^{-1} \mathrm{~h}^{-1}$. The first 2 min were excluded from each linear regression to allow the plants to adjust to the new light level, resulting in a minimum of 24 data points being used in all regressions (i.e. to determine net rate of photosynthesis for each light level). Rates of oxygen production or consumption plotted against light intensity yielded 1 PI curve for each individual plant for each of the 3 time points (Days 0, 1, and 15). Photosynthetic parameters $\left(\alpha, P_{\mathrm{MAX}}, R_{\mathrm{D}}, I_{\mathrm{C}}\right.$ and $\left.I_{\mathrm{SAT}}\right)$ could subsequently be calculated from the plotted curves.

$\alpha$, defined as the initial slope of the PI curve at below-saturating light intensities, was obtained by fitting a linear mixed model (LMM) to a subset of the data including only the first light levels (see Table 1). $I_{C}$, defined as the light requirements for a net photosynthetic rate of zero, was obtained from the same LMM. $P_{\text {MAX }}$ was calculated by averaging 3 values from above-saturating light levels (see Table 1). Subsequently, $I_{\mathrm{SAT}}$ was determined as the intercept between $P_{\mathrm{MAX}}$ and $\alpha . R_{\mathrm{D}}$ was determined as $\mathrm{O}_{2}$ consumption in darkness. Some of the plants exposed to 85 and $170 \mathrm{mg} \mathrm{H}_{2} \mathrm{O}_{2} \mathrm{l}^{-1}$ demonstrated negative $P_{\text {MAX }}$ and/or negative $\alpha$ values. These were excluded (number of included plants is indicated in the figures) when calculating the light parameters $\left(I_{\mathrm{SAT}}\right.$ and $\left.I_{\mathrm{C}}\right)$, as inclusion would have produced unrealistic values.

\subsection{Fitting dose-response curves to determine toxicity potentials}

The extension package $d r c$ version 3.0-1 (Ritz et al. 2015) for R software (R Core Team 2017) was used to model the dose-response relationships. The statistical package provides a range of different regression models, a model-select function, and methods to extract model parameters such as $\mathrm{EC}_{50}, \mathrm{LC}_{50}$, and NEC using the delta method (Ritz et al. 2015). To determine the lethal toxicity potentials, mortality of S. latissima plants on Day 15 was regressed over $\mathrm{H}_{2} \mathrm{O}_{2}$ concentration using the model that gave the best fit: a 2-parameter log-logistic model with a binomial distribution and with the upper and lower asymptotes set to 1 and 0 , respectively:

$$
Y=\frac{1-0}{1+\exp [b(\log (x)-\log (e))]}
$$


where $Y$ is the response, $x$ is the dose, $b$ is the slope of the line, and $e$ is the inflection point of the curve (in this case also the LC $_{50}$ value) (Ritz et al. 2015). To determine the photosynthetic toxicity potentials, the photosynthetic parameters that showed potential for being indicators for immediate effect $\left(P_{\mathrm{MAX}}\right.$ and $\left.\alpha\right)$ were regressed over $\mathrm{H}_{2} \mathrm{O}_{2}$ concentration. The models that gave the best fit were the 3-parameter log-logistic model ( $P_{\text {MAX }}$, Eq. 2 ) and the 3-parameter Weibull 1 model ( $\alpha$, Eq. 3$)$, both models with the lower asymptote set to 0 :

$$
\begin{gathered}
Y=0+\frac{d-0}{1+\exp [b(\log (x)-\log (e))]} \\
Y=0+(d-0) \exp \{-\exp [b(\log (x)-\log (e))]\}
\end{gathered}
$$

where $Y$ is the response, $x$ is the dose, $d$ is the upper asymptote, $b$ is the slope of the line, and $e$ is the inflection point of the curve (Ritz et al. 2015).

\subsection{Statistical analysis}

The effect of $\mathrm{H}_{2} \mathrm{O}_{2}$ concentration on photosynthesis $\left(\alpha, P_{\mathrm{MAX}}, R_{\mathrm{D}}\right)$ was tested by fitting generalized least squares (GLS) models using the package nlme (Pinheiro et al. 2017), where $\mathrm{H}_{2} \mathrm{O}_{2}$ concentration (5 levels: control, 1.7, 17, 85, and $170 \mathrm{mg} \mathrm{l}^{-1}$ ) and time (2 levels: Day 0 and Day 1) were used as fixed effects. Loss of plants in the 85 and $170 \mathrm{mg} \mathrm{l}^{-1}$ concentrations on Day 15 prevented the running of a full statistical model on all time points. As each plant was repeatedly measured over time, 'plant' was treated as a random factor and incorporated with a correlation term, allowing dependency between the response variables from the same plant (Zuur et al. 2009). Heteroscedasticity was obtained by allowing differing variances across $\mathrm{H}_{2} \mathrm{O}_{2}$ concentration for $\alpha$ and $P_{\text {MAX }}$ and across time for $R_{\mathrm{D}}$. The significance of the interaction $\mathrm{H}_{2} \mathrm{O}_{2}$ concentration $\times$ Time and the 2 fixed effects were tested with the likelihood ratio test, and only significant terms were included in the final model (Zuur et al. 2009).

\section{RESULTS}

\subsection{Mortality}

Results from the preliminary study showed 100\% mortality when exposing juvenile sugar kelp Saccharina latissima for $1 \mathrm{~h}$ to the commercially recommended bath-treatment dose of $1700 \mathrm{mg} \mathrm{l}^{-1}$ and for concentrations down to $10 \%\left(170 \mathrm{mg} \mathrm{l}^{-1}\right)$ of this dose (see Appendix).

In the main experiment, no mortality was observed on Day 0 or Day 1 in any of the concentrations ranging from no added $\mathrm{H}_{2} \mathrm{O}_{2}$ (seawater control) to $170 \mathrm{mg}$ $\mathrm{H}_{2} \mathrm{O}_{2} \mathrm{l}^{-1}$. At the end of the $15 \mathrm{~d}$ post-exposure period, mortality had increased to $100 \%$ in the $170 \mathrm{mg} \mathrm{l}^{-1}$ concentration and to $67 \%$ in the $85 \mathrm{mg} \mathrm{l}^{-1}$, while there was no mortality in plants exposed to $17 \mathrm{mg} \mathrm{l}^{-1}$, $1.7 \mathrm{mg} \mathrm{l}^{-1}$, or in the control (Fig. 1). On Day 15, the control plants showed no fragmentation or sign of pigment loss. Plants in the $170 \mathrm{mg} \mathrm{l}^{-1}$ concentration, however, had lost pigments in larger parts of the lamina after $3 \mathrm{~d}$ (Fig. 2A). This was followed by continuous fragmentation until all plants in the $170 \mathrm{mg} \mathrm{l}^{-1}$ concentration were completely disintegrated within $10 \mathrm{~d}$. The same course of events was observed for the 4 plants that died in the $85 \mathrm{mg} \mathrm{l}^{-1}$ concentration: loss of pigments followed by fragmentation and complete disintegration. The $\mathrm{LC}_{50}$ for juvenile $S$. latissima was determined to be $80.7 \pm 53.5 \mathrm{mg} \mathrm{l}^{-1}$ and the NEC to be $72.9 \pm 0.4 \mathrm{mg} \mathrm{l}^{-1}$ (Table 2).

\subsection{Effects on photosynthesis}

The PI relationship of control plants followed a typical pattern at all 3 time points: a linear increase in net photosynthetic rate for below-saturating light intensities ( 0 to 43.5 PAR) followed by a gradual decrease for above-saturating intensities (43.5 to 348 PAR) (Fig. 3). Exposure for $1 \mathrm{~h}$ to concentrations of 170 and $85 \mathrm{mg} \mathrm{H}_{2} \mathrm{O}_{2} \mathrm{l}^{-1}$ resulted in immediate negative impacts on the net photosynthetic rate on Day 0 , reducing the median $( \pm \mathrm{SD})$ rate compared to

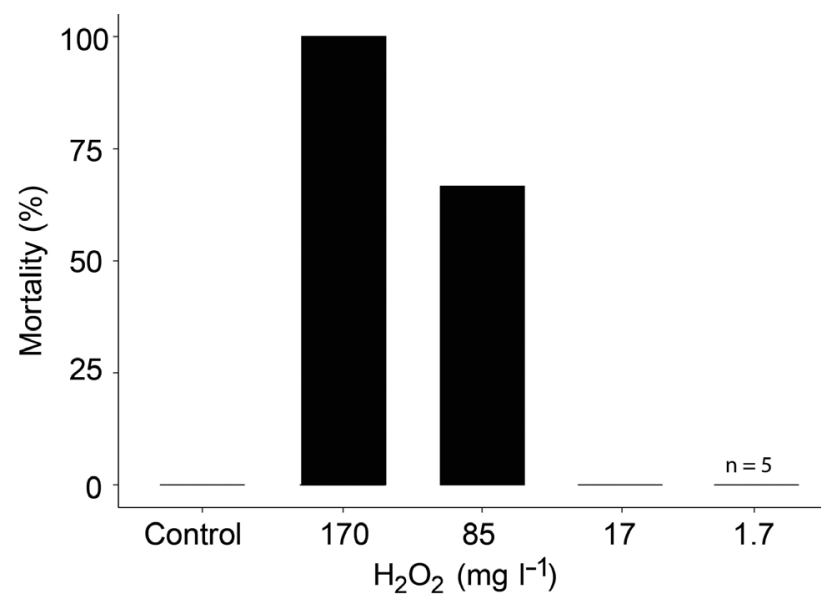

Fig. 1. Mortality of juvenile Saccharina latissima plants $15 \mathrm{~d}$ after $1 \mathrm{~h}$ exposure to 5 different $\mathrm{H}_{2} \mathrm{O}_{2}$ concentrations, including control ( $\mathrm{n}=6$ unless otherwise stated) 


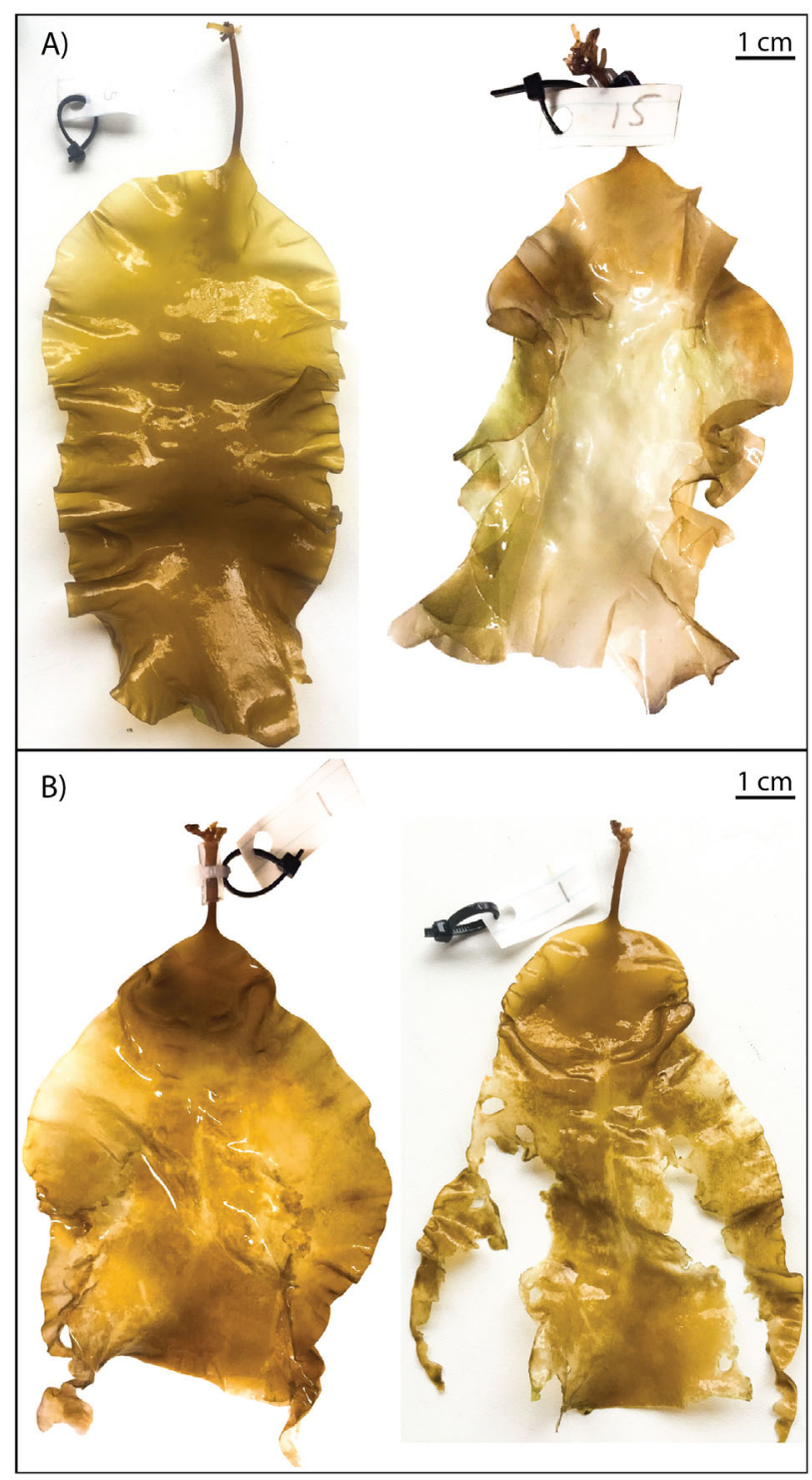

Fig. 2. Effects of different concentrations of $\mathrm{H}_{2} \mathrm{O}_{2}$ on lamina of juvenile Saccharina latissima plants at different time intervals. (A) Normal lamina with no visible damages $15 \mathrm{~d}$ post-exposure to concentrations $\leq 17 \mathrm{mg} \mathrm{l}^{-1}$ (left), and discoloured and pale lamina $3 \mathrm{~d}$ post-exposure to $170 \mathrm{mg} \mathrm{l}^{-1}$ (right); (B) discoloured lamina due to pigment loss $8 \mathrm{~d}$ postexposure to $85 \mathrm{mg} \mathrm{l}^{-1}$ (left), and lamina with loss of tissue due to cell death $15 \mathrm{~d}$ post-exposure to $85 \mathrm{mg} \mathrm{l}^{-1}$ (right)

that of the control plants at both below-saturating irradiance (43.5 PAR; control: $13.99 \pm 3.73 \mu \mathrm{mol} \mathrm{O}{ }_{2}$ $\mathrm{gFW}^{-1} \mathrm{~h}^{-1} ; 170 \mathrm{mg} \mathrm{l}^{-1}:-0.72 \pm 1.01 \mu \mathrm{mol} \mathrm{O}_{2} \mathrm{gFW}^{-1}$ $\mathrm{h}^{-1} ; 85 \mathrm{mg} \mathrm{l}^{-1}: 0.17 \pm 1.27 \mu \mathrm{mol} \mathrm{O}_{2} \mathrm{gFW}^{-1} \mathrm{~h}^{-1}$ ) and at the highest irradiance (348.5 PAR; control: $45.62 \pm$ $8.77 \mu \mathrm{mol} \mathrm{O}_{2} \mathrm{gFW}^{-1} \mathrm{~h}^{-1} ; 170 \mathrm{mg} \mathrm{l}^{-1}:-0.77 \pm 3.64 \mu \mathrm{mol}$ $\mathrm{O}_{2} \mathrm{gFW}^{-1} \mathrm{~h}^{-1} ; 85 \mathrm{mg} \mathrm{l}^{-1}: 0.59 \pm 3.37 \mu \mathrm{mol} \mathrm{O}_{2} \mathrm{gFW}^{-1}$ $\left.\mathrm{h}^{-1}\right)$. A slightly lower median $( \pm \mathrm{SD})$ net photosynthesis was demonstrated by plants in the $17 \mathrm{mg} \mathrm{H}_{2} \mathrm{O}_{2} \mathrm{l}^{-1}$
Table 2 . Toxicity potentials $\left( \pm 95 \% \mathrm{CI}, \mathrm{mg} \mathrm{l}^{-1}\right.$ ) of a $1 \mathrm{~h}$ exposure to $\mathrm{H}_{2} \mathrm{O}_{2}$ on juvenile Saccharina latissima for mortality and photosynthesis ( $\alpha$ : photosynthetic capacity, $P_{\mathrm{MAX}}$ : photosynthetic efficiency). $\mathrm{LC}_{50}$ and $\mathrm{LC}_{90}$ : median lethal concentrations and $\mathrm{EC}_{50}$ and $\mathrm{EC}_{90}$ : median effective concentrations, for $50 \%$ and $90 \%$ of the population, respectively; NEC: no-effect concentration

\begin{tabular}{|lccc|}
\hline & $\mathrm{LC}_{50}$ & $\mathrm{LC}_{90}$ & $\mathrm{NEC}$ \\
\hline Mortality & $80.7 \pm 53.5$ & $95.1 \pm 134.1$ & $72.9 \pm 0.4$ \\
& $\mathrm{EC}_{50}$ & $\mathrm{EC}_{90}$ & $\mathrm{NEC}$ \\
\hline$\alpha$ & $35.4 \pm 13.4$ & $77.7 \pm 40.7$ & $13.1 \pm 11.2$ \\
$\mathrm{P}_{\mathrm{MAX}}$ & $27.8 \pm 9.1$ & $57.5 \pm 39.8$ & $13.1 \pm 11.2$ \\
\hline
\end{tabular}

concentration immediately post-exposure at high light intensities (148 PAR: $31.92 \pm 7.15 \mu \mathrm{mol} \mathrm{O}_{2}$ $\mathrm{gFW}^{-1} \mathrm{~h}^{-1}$; 348.5 PAR: $33.47 \pm 4.46 \mu \mathrm{mol} \mathrm{O} \mathrm{gFW}^{-1}$ $\mathrm{h}^{-1}$ ) compared to the control (148 PAR: $37.22 \pm$ $5.85 \mu \mathrm{mol} \mathrm{O}_{2} \mathrm{gFW}^{-1} \mathrm{~h}^{-1}$ ), though not at the lower intensities. Plants exposed to $1.7 \mathrm{mg} \mathrm{l}^{-1}$ concentration showed comparable median net photosynthesis across all irradiances to the control.

On Day 1, photosynthetic rates of $S$. latissima plants exposed to $\geq 85 \mathrm{mg} \mathrm{H}_{2} \mathrm{O}_{2} \mathrm{l}^{-1}$ were still heavily impacted at all light intensities, showing highly reduced maximum rates compared to the control plants (control: $41.87 \pm 5.40 \mu \mathrm{mol} \mathrm{O}_{2} \mathrm{gFW}^{-1} \mathrm{~h}^{-1} ; 170 \mathrm{mg} \mathrm{l}^{-1}$ : $0.40 \pm 3.02 \mu \mathrm{mol} \mathrm{O}_{2} \mathrm{gFW}^{-1} \mathrm{~h}^{-1} ; 85 \mathrm{mg} \mathrm{l}^{-1}: 8.15 \pm$ $5.07 \mu \mathrm{mol} \mathrm{O} \mathrm{gFW}^{-1} \mathrm{~h}^{-1}$; median $\pm \mathrm{SD}$ ). Net photosynthetic rates of plants in the 17 and $1.7 \mathrm{mg} \mathrm{l}^{-1}$ concentrations were similar to that of the control for all light intensities.

On Day 15, control plants showed a lower median net photosynthesis compared to Day 0: $9.65 \pm$ $1.77 \mu \mathrm{mol} \mathrm{O}_{2} \mathrm{gFW}^{-1} \mathrm{~h}^{-1}$ at $43.5 \mathrm{PAR}^{2} 18.14 \pm 3.84$ $\mu \mathrm{mol} \mathrm{O} \mathrm{gFW}^{-1} \mathrm{~h}^{-1}$ at $148 \mathrm{PAR}$, and $24.87 \pm 4.64 \mu \mathrm{mol}$ $\mathrm{O}_{2} \quad \mathrm{gFW}^{-1} \mathrm{~h}^{-1}$ at the highest light intensity (348.5 PAR). The 2 surviving plants in the $85 \mathrm{mg} \mathrm{l}^{-1}$ concentration still showed signs of impact from the $\mathrm{H}_{2} \mathrm{O}_{2}$ exposure under light intensities up to 171.5 PAR, demonstrating a $50 \%$ reduction in net photosynthesis, while the response to high light $>200$ PAR appeared to have recovered more.

The reduced net photosynthetic rate found for plants exposed to concentrations $\geq 85 \mathrm{mg} \mathrm{l}^{-1}$ resulted in a drop in $\alpha$ and $P_{\mathrm{MAX}}$ on Day 0 compared with the control plants (Fig. 4). Median ( $\pm \mathrm{SD}) \alpha$-value for the 2 highest concentrations (170 $\mathrm{mg} \mathrm{l}^{-1}: 0.00 \pm 0.01 \mu \mathrm{mol}$ $\mathrm{O}_{2} \mathrm{gFW}^{-1} \mathrm{~h}^{-1} / \mu \mathrm{mol} \mathrm{m}{ }^{-2} \mathrm{~s}^{-1} ; 85 \mathrm{mg} \mathrm{l}^{-1}: 0.02 \pm$ $0.03 \mu \mathrm{mol} \mathrm{O}_{2} \mathrm{gFW}^{-1} \mathrm{~h}^{-1} / \mu \mathrm{mol} \mathrm{m}{ }^{-2} \mathrm{~s}^{-1}$ ) were significantly different $(p<0.001$, Table 3$)$ from the control 

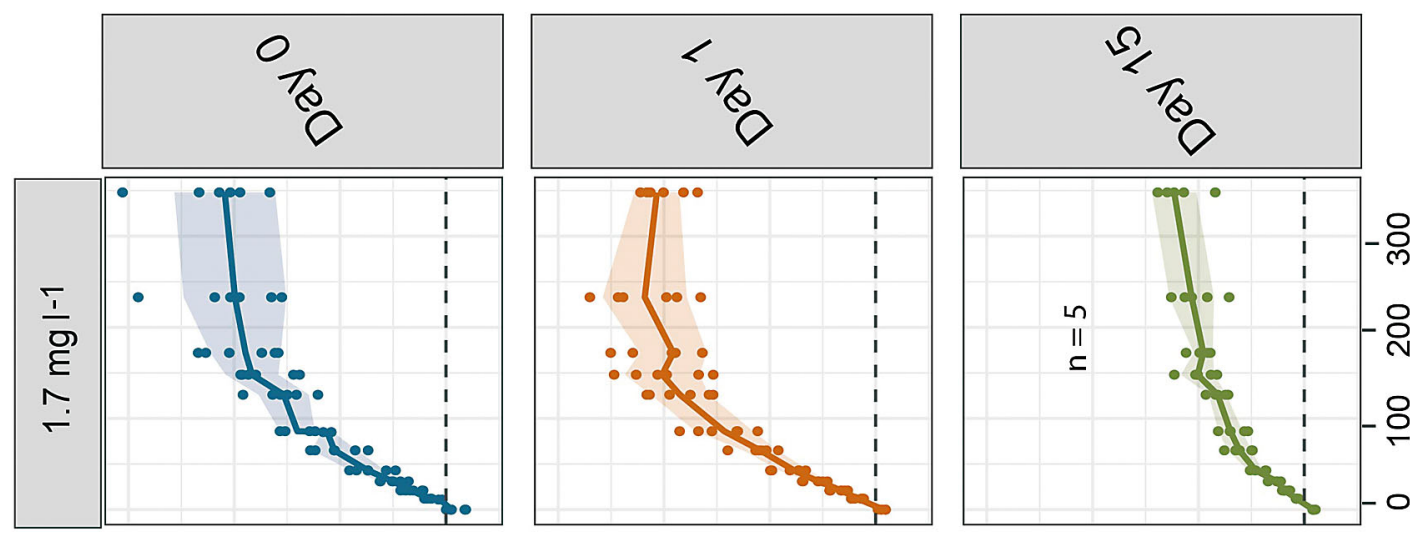

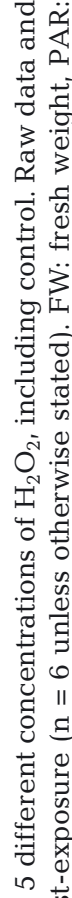
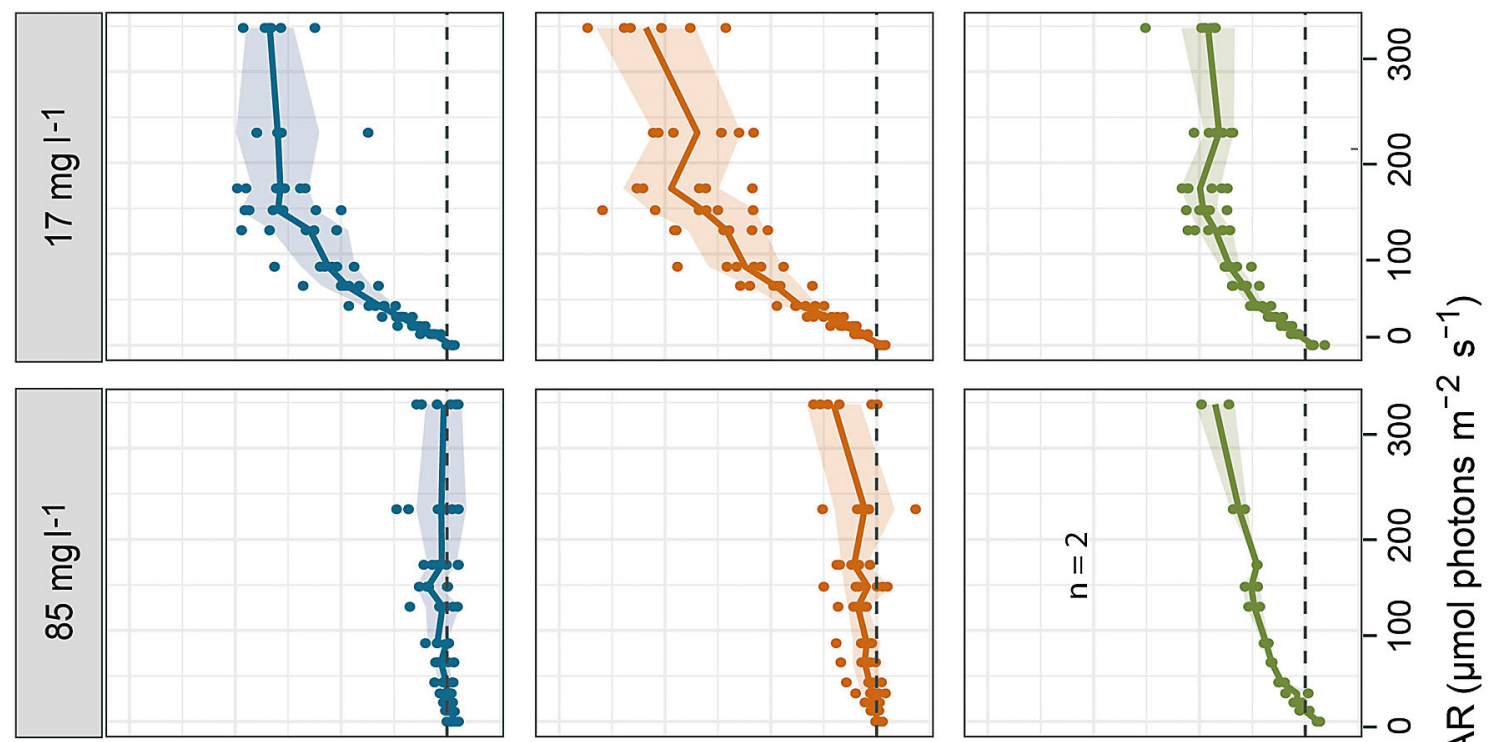

I 1080

$\varepsilon=\tau: 0$

๑

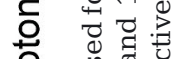

등

8

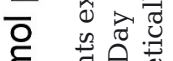

至
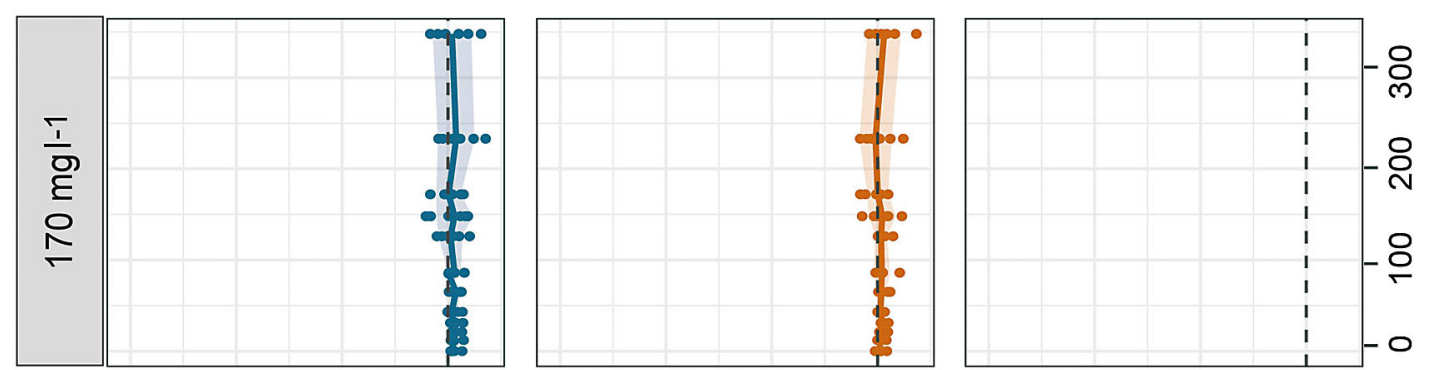

采

종

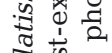
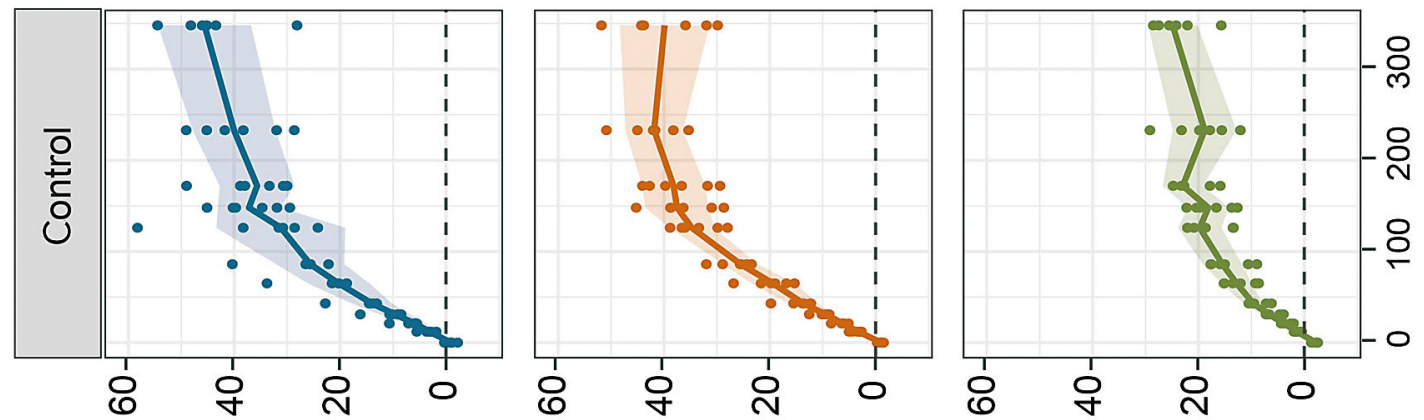

-

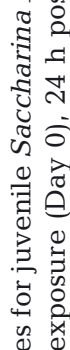

( ᄂ- ${ }_{\text {L- }} M \pm 6 z_{0}$ |our)

s!səuluKsoloud łəN

它

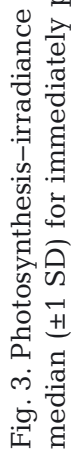



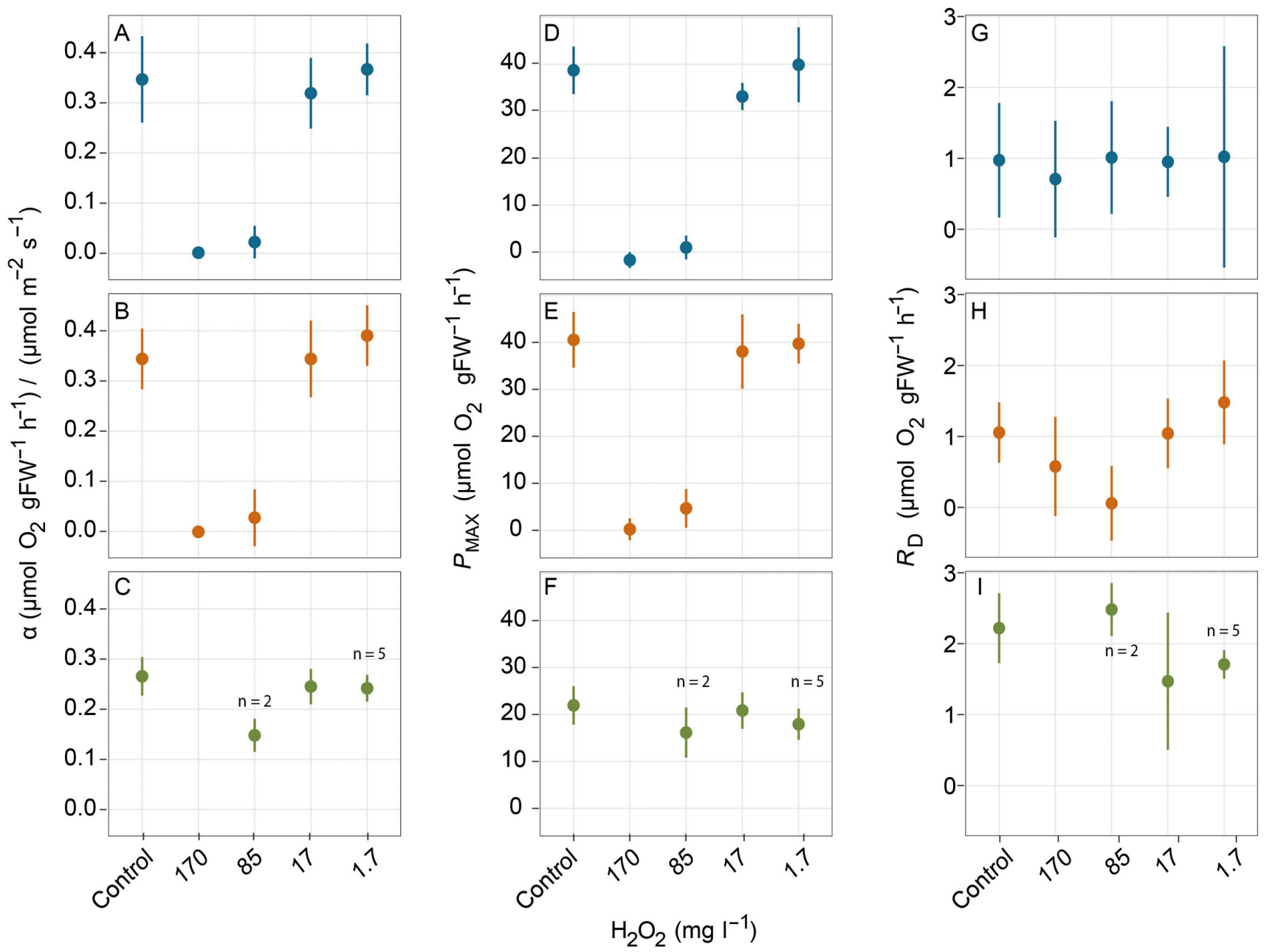

Fig. 4. Effect after $1 \mathrm{~h}$ exposure to 5 different concentrations of $\mathrm{H}_{2} \mathrm{O}_{2}$, including control, on photosynthetic parameters (A-C: $\alpha$ : photosynthetic efficiency, D-F: $P_{\mathrm{MAx}}$ : maximum photosynthetic rate at high light, $\mathrm{G}-\mathrm{I}: R_{\mathrm{D}}$ : respiration rate in the dark) of juvenile Saccharina latissima plants. Median $( \pm 1 \mathrm{SD})$ response $(\mathrm{A}, \mathrm{D}, \mathrm{G})$ immediately post-exposure $($ Day 0$),(\mathrm{B}, \mathrm{E}, \mathrm{H}) 24 \mathrm{~h}$ postexposure (Day 1), and ( $\mathrm{C}, \mathrm{F}, \mathrm{I}) 15 \mathrm{~d}$ post-exposure $(\mathrm{n}=6$ unless otherwise stated). FW: fresh weight

$\left(0.35 \pm 0.09 \mu \mathrm{mol} \mathrm{O}_{2} \mathrm{gFW}^{-1} \mathrm{~h}^{-1} / \mu \mathrm{mol} \mathrm{m}{ }^{-2} \mathrm{~s}^{-1}\right)$. For concentrations $\leq 17 \mathrm{mg} \mathrm{l}^{-1}$, however, there were no significant differences compared to the control (17 $\mathrm{mg} \mathrm{l}^{-1}: 0.32 \pm 0.07 \mu \mathrm{mol} \mathrm{O} \mathrm{gFW}^{-1} \mathrm{~h}^{-1} / \mu \mathrm{mol} \mathrm{m}^{-2}$ $\mathrm{s}^{-1}, \mathrm{p}=0.429 ; 1.7 \mathrm{mg} \mathrm{l}^{-1}: 0.37 \pm 0.05 \mu \mathrm{mol} \mathrm{O} \mathrm{gFW}^{-1}$ $\mathrm{h}^{-1} / \mu \mathrm{mol} \mathrm{m}{ }^{-2} \mathrm{~s}^{-1}, \mathrm{p}=0.543$; median $\pm \mathrm{SD}$ ). No significant $\mathrm{H}_{2} \mathrm{O}_{2}$ concentration $\times$ time interaction $(\mathrm{p}=$ $0.078, \mathrm{df}=2$ ) or significant differences between Day 0 and Day $1(p=0.615, d f=11)$ were found; hence $\alpha$ was equally unaffected by time in all concentrations.

The median $( \pm \mathrm{SD}) P_{\mathrm{MAX}}$ for plants in the 170 and $85 \mathrm{mg} \mathrm{l}^{-1}$ concentrations $(-1.70 \pm 1.69$ and $0.97 \pm$ $2.50 \mu \mathrm{mol} \mathrm{O}_{2} \mathrm{gFW}^{-1} \mathrm{~h}^{-1}$, respectively) were significantly different to that of the control (38.71 \pm $\left.5.04 \mu \mathrm{mol} \mathrm{O}_{2} \mathrm{gFW}^{-1} \mathrm{~h}^{-1}\right)$ on Day $0(\mathrm{p}<0.001$, Table 3$)$. For plants exposed to $17 \mathrm{mg} \mathrm{l}^{-1}$, the median $P_{\mathrm{MAX}}$ $( \pm \mathrm{SD})$ was lower $\left(33.15 \pm 2.88 \mu \mathrm{mol} \mathrm{O}_{2} \mathrm{gFW}^{-1} \mathrm{~h}^{-1}\right)$ than that of the control plants, but neither this nor the $P_{\mathrm{MAX}}$ of plants exposed to $1.7 \mathrm{mg} \mathrm{l}^{-1}$ were significantly different to the control $\left(17 \mathrm{mg} \mathrm{l}^{-1}: \mathrm{p}=0.077\right.$; $\left.1.7 \mathrm{mg} \mathrm{l}^{-1}: \mathrm{p}=0.594\right)$. No significant $\mathrm{H}_{2} \mathrm{O}_{2}$ concentration $\times$ time interaction $(\mathrm{p}=0.531, \mathrm{df}=2)$ or significant differences between Day 0 and Day $1(\mathrm{p}=0.125$, $\mathrm{df}=$ 11) were found; hence $P_{\text {MAX }}$ was equally unaffected by time in all concentrations.

Based on these results, the $\mathrm{EC}_{50}$ for $\alpha$ for juvenile $S$. latissima plants to $\mathrm{H}_{2} \mathrm{O}_{2}$ exposure was determined to $35.4 \pm 13.4 \mathrm{mg} \mathrm{l}^{-1}$, while the $\mathrm{EC}_{50}$ for $P_{\mathrm{MAX}}$ was determined to $27.8 \pm 9.1 \mathrm{mg} \mathrm{l}^{-1}$ (Table 2). The determined NEC value for both photosynthetic parameters was $13.1 \pm 11.2 \mathrm{mg} \mathrm{l}^{-1}$.

Median $( \pm \mathrm{SD})$ respiration rate $\left(R_{\mathrm{D}}\right)$ was not affected in any concentration on Day 0 compared to the control $\left(0.97 \pm 0.81 \mu \mathrm{mol} \mathrm{O}_{2} \mathrm{gFW}^{-1} \mathrm{~h}^{-1}\right)$ (Fig. 4). On Day 1, me- 
Table 3. Estimated regression parameters $\left(\mathrm{H}_{2} \mathrm{O}_{2}\right.$ concentration, and time), standard error (SE), $t$-values, and p-values from generalized least squares (GLS) models fitted to the photosynthetic response variables. Only significant terms were included in the final models

\begin{tabular}{|c|c|c|c|c|}
\hline $\begin{array}{l}\text { Source of } \\
\text { variation }\end{array}$ & Estimate & $\mathrm{SE}$ & $t$ & $\mathrm{p}$ \\
\hline \multicolumn{5}{|c|}{$\alpha$ (photosynthetic efficiency) } \\
\hline Intercept & 0.36808 & 0.024391 & 15.09055 & $<0.001$ \\
\hline $1.7 \mathrm{mg} \mathrm{l}^{-1}$ & 0.021754 & 0.035521 & 0.612437 & 0.543 \\
\hline $17 \mathrm{mg} \mathrm{l}^{-1}$ & -0.02804 & 0.035201 & -0.79665 & 0.429 \\
\hline $85 \mathrm{mg} \mathrm{l}^{-1}$ & -0.33031 & 0.029399 & -11.2355 & $<0.001$ \\
\hline $170 \mathrm{mg} \mathrm{l}^{-1}$ & -0.3708 & 0.024876 & -14.906 & $<0.001$ \\
\hline \multicolumn{5}{|c|}{$P_{\text {MAX }}$ (photosynthetic rate at high light) } \\
\hline Intercept & 39.88723 & 1.625547 & 24.53773 & $<0.001$ \\
\hline $1.7 \mathrm{mg} \mathrm{l}^{-1}$ & 1.36651 & 2.545536 & 0.536824 & 0.594 \\
\hline $17 \mathrm{mg} \mathrm{l}^{-1}$ & -4.48864 & 2.49097 & -1.80197 & 0.077 \\
\hline $85 \mathrm{mg} \mathrm{l}^{-1}$ & -36.8761 & 1.956721 & -18.8459 & $<0.001$ \\
\hline $170 \mathrm{mg} \mathrm{l}^{-1}$ & -40.7071 & 1.746224 & -23.3115 & $<0.001$ \\
\hline \multicolumn{5}{|c|}{$R_{\mathrm{D}}$ (respiration rate at low light) } \\
\hline Intercept & 1.2415940 & 0.2714216 & 4.574411 & $<0.001$ \\
\hline $1.7 \mathrm{mg} \mathrm{l}^{-1}$ & 0.4078867 & 0.3196865 & 1.275896 & 0.208 \\
\hline $17 \mathrm{mg} \mathrm{l}^{-1}$ & 0.1167600 & 0.3196865 & 0.365233 & 0.716 \\
\hline $85 \mathrm{mg} \mathrm{l}^{-1}$ & -0.7006096 & 0.3196865 & -2.191552 & 0.033 \\
\hline $170 \mathrm{mg} \mathrm{l}^{-1}$ & -0.3700247 & 0.3196865 & -1.157461 & 0.252 \\
\hline Day 1 & -0.2961013 & 0.1466637 & -2.018913 & 0.049 \\
\hline
\end{tabular}

$107 \pm 17$ PAR) and Day 1 (control: $108 \pm$ $14 \mathrm{PAR}_{;} 17 \mathrm{mg} \mathrm{l}^{-1}$ : $102 \pm 19 \mathrm{PAR} 1.7 \mathrm{mg} \mathrm{l}^{-1}$ : $101 \pm 13$ PAR) (Fig. 5)

Median $I_{\mathrm{C}}( \pm \mathrm{SD})$ was 98 and 9 times higher on Day 0 for plants in concentrations $170 \mathrm{mg} \mathrm{l}^{-1}$ $(297 \pm 2034 \mathrm{PAR})$ and $85 \mathrm{mg} \mathrm{l}^{-1}(29 \pm 141 \mathrm{PAR})$, respectively, compared to the control $(3 \pm 2$ PAR) (Fig. 6). The higher $I_{\mathrm{C}}$ was attributed to the drop in $\alpha$ values, as there was no acute effect on $R_{\mathrm{D}}$ (Fig. 4). Due to the high variation (SD), the values were deemed uncertain, as was the $I_{\mathrm{C}}$ for the same concentrations on Day 1 (170 $\mathrm{mg} \mathrm{l}^{-1}$ : $231 \pm 245 \mathrm{PAR} 85 \mathrm{mg} \mathrm{l}^{-1}$ : $14 \pm 14$ PAR), and further interpretation was not conducted. The median $( \pm \mathrm{SD}) I_{\mathrm{C}}$ for the $17 \mathrm{mg}$ $\mathrm{l}^{-1}(3 \pm 1 \mathrm{PAR})$ and $1.7 \mathrm{mg} \mathrm{l}^{-1}(3 \pm 3 \mathrm{PAR})$ concentrations were comparable to the control. On Day 1 , the $I_{\mathrm{C}}$ showed no change for the $\leq 17 \mathrm{mg}$ $\mathrm{l}^{-1}$ concentrations, including for the control (control: $3 \pm 1$ PAR; $17 \mathrm{mg} \mathrm{l}^{-1}: 3 \pm 1 \mathrm{PAR}_{;} 1.7 \mathrm{mg}$ $1^{-1}: 3 \pm 1$ PAR).

\subsection{Prolonged effects of $\mathrm{H}_{2} \mathrm{O}_{2}$}

dian $( \pm \mathrm{SD}) R_{\mathrm{D}}$ was significantly reduced to $0.06 \pm$ $0.53 \mu \mathrm{mol} \mathrm{O}_{2} \mathrm{gFW}^{-1} \mathrm{~h}^{-1}$ for plants exposed to $85 \mathrm{mg} \mathrm{l}^{-1}$ ( $\mathrm{p}=0.033$, Table 3 ). The $R_{\mathrm{D}}$ of plants in concentrations 170 and $\leq 17 \mathrm{mg} \mathrm{l}^{-1}$ were not significantly different to that of the control $\left(170 \mathrm{mg} \mathrm{l}^{-1}: \mathrm{p}=0.252 ; 17 \mathrm{mg} \mathrm{l}^{-1}\right.$ : $\mathrm{p}=0.716 ; 1.7 \mathrm{mg} \mathrm{l}^{-1}: \mathrm{p}=0.208$; Table 3$)$. Unlike $P_{\mathrm{MAX}}$ and $\alpha$, there was a significant difference over time from Day 0 to Day 1 ( $p=0.049$, Table 3$)$, most likely related to the change in the $85 \mathrm{mg} \mathrm{l}^{-1}$ concentration. The interaction $\mathrm{H}_{2} \mathrm{O}_{2}$ concentration $\times$ time was nonsignificant $(\mathrm{p}=0.130$, $\mathrm{df}=2)$.

Median $( \pm \mathrm{SD}) I_{\mathrm{SAT}}$ was reduced to $57 \pm 36 \mathrm{PAR}$ for plants exposed to $85 \mathrm{mg} \mathrm{l}^{-1}$ on Day 0 compared to the control (106 $\pm 16 \mathrm{PAR}$ ) (Fig. 5). This reduction was caused by the observed drop in $P_{\text {MAX }}$ and $\alpha$. In the $170 \mathrm{mg} \mathrm{l}^{-1}$ concentration, only 1 plant met the criteria (see 'Materials and methods') to calculate the $I_{\text {SAT }}$ (9861 PAR). On Day 1, the variation (SD) around the median was highly inflated for plants exposed to these 2 concentrations $\left(170 \mathrm{mg} \mathrm{l}^{-1}: 511 \pm 459 \mathrm{PAR}_{\text {; }}\right.$ $\left.85 \mathrm{mg} \mathrm{l}^{-1}: 89 \pm 305 \mathrm{PAR}\right)$ compared to the control (108 \pm 13 PAR). Due to the high variation, and in 1 case, lack of replicates, further interpretation of this response parameter for plants exposed to $\geq 85 \mathrm{mg} \mathrm{l}^{-1}$ on Day 0 and Day 1 may be misleading and is thus avoided (Fig. 5). For concentrations $\leq 17 \mathrm{mg} \mathrm{l}^{-1}$, the median $( \pm \mathrm{SD}) I_{\mathrm{SAT}}$ values were similar to the control both on Day $0\left(17 \mathrm{mg} \mathrm{l}^{-1}\right.$ : $102 \pm 13 \mathrm{PAR}_{i} 1.7 \mathrm{mg} \mathrm{l}^{-1}$ :
On Day 15, median $( \pm \mathrm{SD}) \alpha$ of control plants was $0.27 \pm 0.04 \mu \mathrm{mol} \mathrm{O} \mathrm{gFW}^{-1} \mathrm{~h}^{-1} / \mu \mathrm{mol} \mathrm{m}^{-2} \mathrm{~s}^{-1}$ (Fig. 4) The 2 plants that survived the $85 \mathrm{mg} \mathrm{l}^{-1}$ concentration demonstrated a $50 \%$ reduction in $\alpha(0.15 \pm 0.03 \mu \mathrm{mol}$ $\mathrm{O}_{2} \mathrm{gFW}^{-1} \mathrm{~h}^{-1} / \mu \mathrm{mol} \mathrm{m} \mathrm{m}^{-2} \mathrm{~s}^{-1}$ ) compared to the control (Fig. 4), causing a $50 \%$ higher $I_{\mathrm{C}}\left(85 \mathrm{mg} \mathrm{l}^{-1}: 15 \pm\right.$ 6 PAR, control: $7 \pm 2$ PAR) (Fig. 6). The other parameters $\left(P_{\mathrm{MAX}}, R_{\mathrm{D}}\right.$, and $\left.I_{\mathrm{SAT}}\right)$ were comparable to the control for all concentrations. The parameters of the control plants had changed over time; the $P_{\text {MAX }}$ and $\alpha$ showed a reduction of $24 \%$ and $20 \%$, respectively, while $R_{\mathrm{D}}$ had increased from $0.97 \pm 0.81$ to $2.22 \pm$ $0.49 \mu \mathrm{mol} \mathrm{O} \mathrm{gFW} \mathrm{h}^{-1}$, leading to a higher $I_{\mathrm{C}}$ of $7 \pm$ 1 PAR and a lower $I_{\text {SAT }}$ of $81 \pm 30$ PAR.

The 2 plants that survived the $85 \mathrm{mg} \mathrm{l}^{-1}$ concentration had the highest initial biomass compared to other plants in the same concentration. Some loss of pigments was observed after $8 \mathrm{~d}$, shown as paler patches on the lamina (Fig. 2B). Reduced structural integrity of the lamina was observed in the same areas as the pigment loss, leading to tearing. After $15 \mathrm{~d}$, these patches had disintegrated, leaving a degraded lamina (Fig. 2B). A $20 \%$ reduction in biomass from Day 0 to Day 15 was demonstrated by these 2 plants, whereas plants in the control showed an average increase of $105 \%$ (Fig. 7). Plants in the 17 and $1.7 \mathrm{mg} \mathrm{l}^{-1}$ concentrations showed respectively $88 \%$ and $110 \%$ increase in biomass in the same period (Fig. 7). 

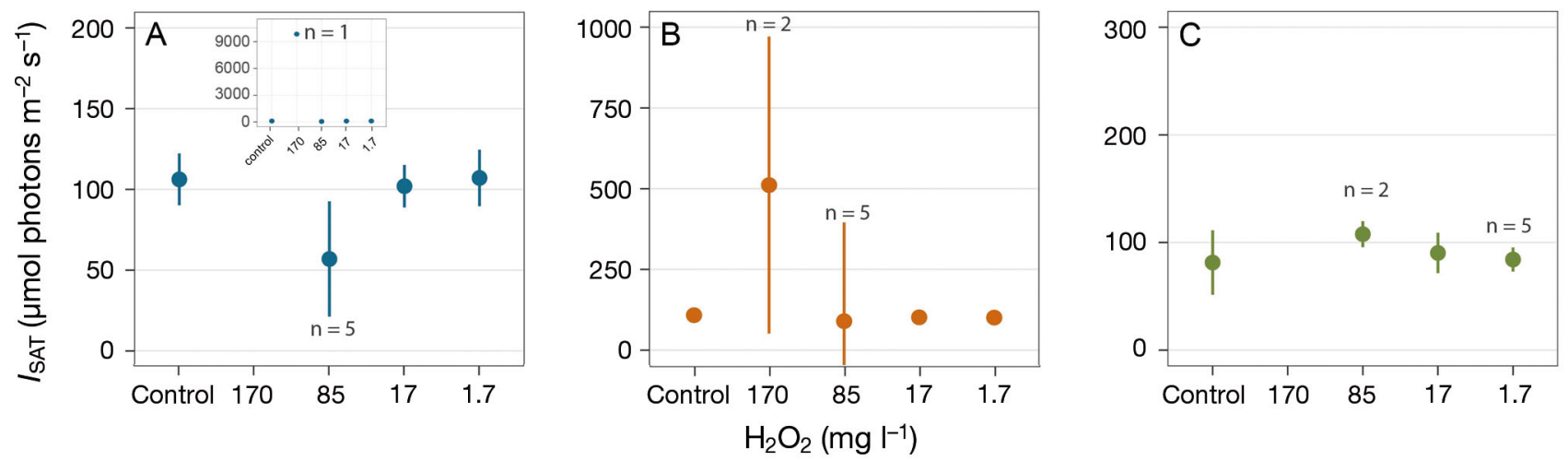

Fig. 5. Effect of $1 \mathrm{~h}$ exposure to 5 different concentrations of $\mathrm{H}_{2} \mathrm{O}_{2}$, including control, on the saturating irradiance ( $\left.I_{\mathrm{SAT}}\right)$ of juvenile Saccharina latissima plants. Median ( $\pm 1 \mathrm{SD}$ ) response (A) immediately post-exposure (Day 0), (B) 24 h post-exposure (Day 1), and (C) $15 \mathrm{~d}$ post-exposure ( $\mathrm{n}=6$ unless otherwise stated). Note different $y$-axis scales. Inset: zoomed-out view of plant $I_{\mathrm{SAT}}$
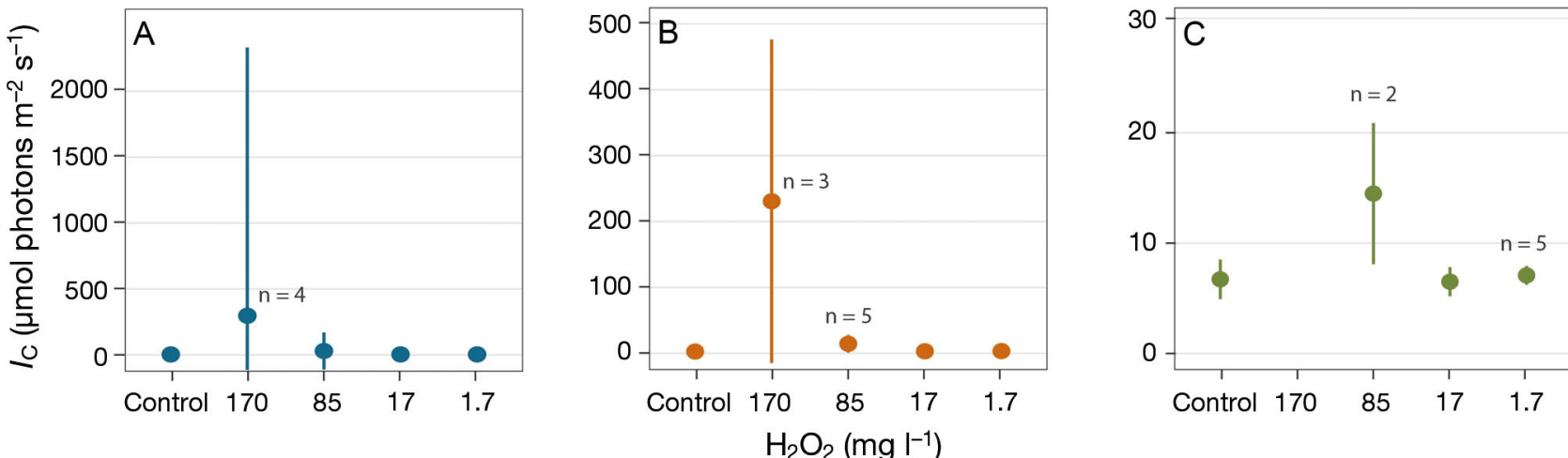

Fig. 6. Effect of $1 \mathrm{~h}$ exposure to 5 different concentrations of $\mathrm{H}_{2} \mathrm{O}_{2}$, including control, on the light compensation irradiance $\left(I_{\mathrm{C}}\right)$ of juvenile Saccharina latissima plants. Median ( $\pm 1 \mathrm{SD}$ ) response (A) immediately post-exposure (Day 0), (B) $24 \mathrm{~h}$ postexposure (Day 1), and (C) 15 d post-exposure ( $\mathrm{n}=6$ unless otherwise stated). Note different $y$-axis scales
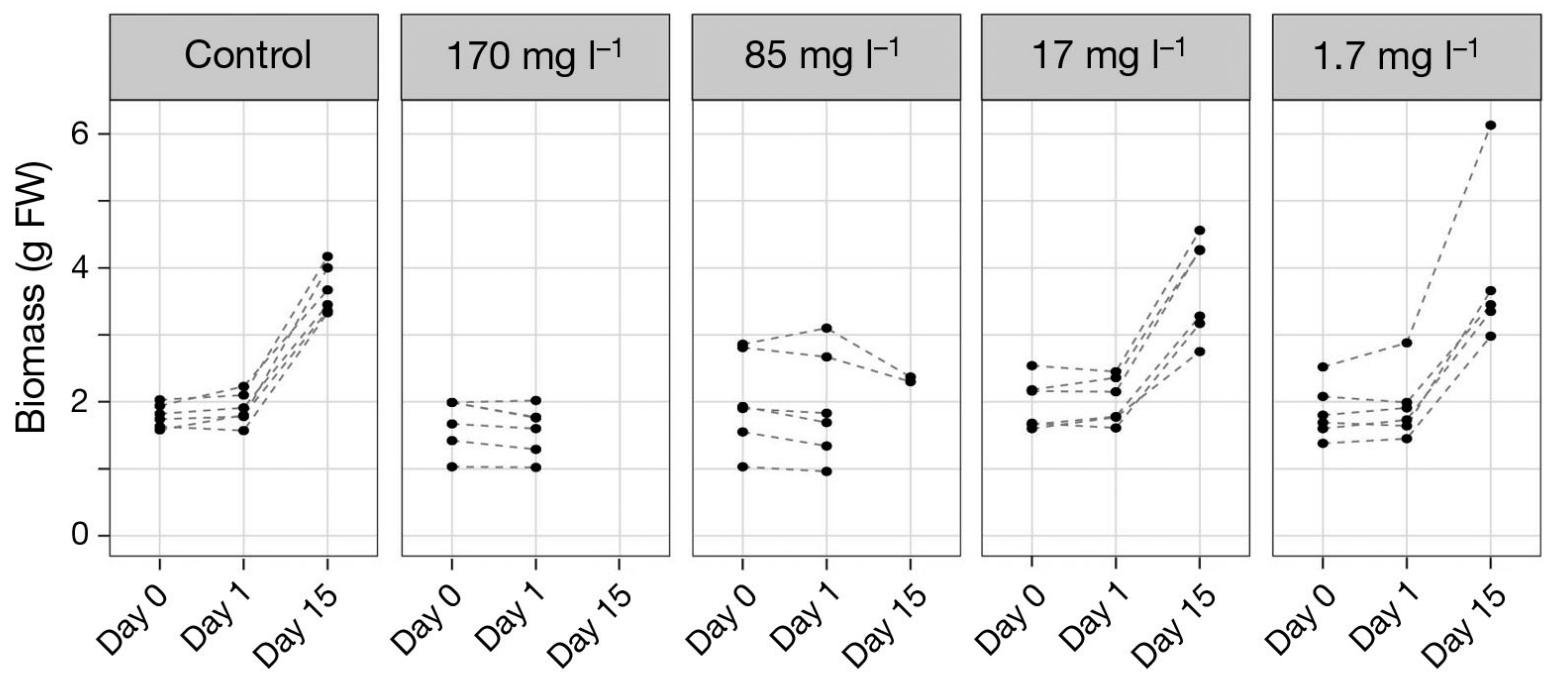

Fig. 7. Effect of $1 \mathrm{~h}$ exposure to 5 different concentrations of $\mathrm{H}_{2} \mathrm{O}_{2}$, including control, on biomass of individual juvenile Saccharina latissima plants over time at intervals immediately post-exposure (Day 0), 24 h post-exposure (Day 1), and 15 d postexposure. FW: fresh weight 


\section{DISCUSSION}

This study demonstrates for the first time the potential consequences of emissions of $\mathrm{H}_{2} \mathrm{O}_{2}$, a common sea-lice therapeutant in salmon farming, on the survival and photosynthetic performance of the habitat-building sugar kelp Saccharina latissima in marine ecosystems. Mortality of juvenile S. latissima was observed for plants exposed to concentrations as low as $85 \mathrm{mg} \mathrm{l}^{-1}$, equivalent to only $5 \%$ of the treatment dose commonly used in net pens $\left(1700 \mathrm{mg} \mathrm{l}^{-1}\right)$. The impact of an $\mathrm{H}_{2} \mathrm{O}_{2}$ concentration of $85 \mathrm{mg} \mathrm{l}^{-1}$ and higher was immediate, reducing both $P_{\text {MAX }}$ and $\alpha$ by $>90 \%$. Furthermore, we saw prolonged effects $15 \mathrm{~d}$ post-exposure for individuals that survived the $85 \mathrm{mg}$ $1^{-1}$ concentration, both in terms of decreased biomass and reduced $\alpha$ and $I_{C}$. The $\mathrm{LC}_{50}$ and $\mathrm{EC}_{50}$ values indicate that $S$. latissima is highly sensitive to $\mathrm{H}_{2} \mathrm{O}_{2}$ levels that natural local populations could be exposed to from aquaculture emissions.

\subsection{Lethal effects of $\mathrm{H}_{2} \mathrm{O}_{2}$}

The highly reduced photosynthetic performance and subsequent mortality of $83 \%$ of the plants exposed to concentrations $\geq 85 \mathrm{mg} \mathrm{l}^{-1}$ strongly indicates that the antioxidative scavenging system of juvenile $S$. latissima was not able to cope with $\mathrm{H}_{2} \mathrm{O}_{2}$ concentrations this high, and that oxidative stress occurred. Oxidative stress caused by $\mathrm{H}_{2} \mathrm{O}_{2}$ may lead to irreversible damages through the auto-destruction of cells (e.g. membrane leakage, oxidation of lipids) and inhibition of photosynthesis (Davison 1991, Collén \& Pedersén 1996, Dummermuth et al. 2003). The observed pigment loss and more flaccid lamina that preceded mortality suggest that oxidation of pigments, membrane leakage, and cell death are possible main causes for the reduced photosynthesis and ultimate plant mortality seen in this study. Inhibition and destruction of photosystem II may also have played a role, as has been suggested as a cause for cell death post- $\mathrm{H}_{2} \mathrm{O}_{2}$ exposure of the macroalgae sea lettuce Ulva rigida (Collén \& Pedersén 1996), though this was not tested in this study.

A much lower $\mathrm{H}_{2} \mathrm{O}_{2}$ concentration caused mortality for U. rigida (10.2 $\mathrm{mg} \mathrm{l}^{-1}$; Collén \& Pedersén 1996) than for $S$. latissima (85 $\mathrm{mg} \mathrm{l}^{-1}$; present study). The difference could be related to plant structure, as a higher stress tolerance has been linked to the thickness of the thallus (Roleda et al. 2007). S. latissima has a thicker, corticated, and thus more complex thallus structure than $U$. rigida, which has distro- matic (2 cell-layers thick) thallus (Bold \& Wynne 1978). Furthermore, the Laminariales contain the carbohydrate mannitol that can act as an antioxidant and stabilize proteins (Bartsch et al. 2008). The use of whole plants in the present study compared to tissue discs ( $2 \mathrm{~cm}$ in diameter) in the $U$. rigida study might have also influenced mortality; $\mathrm{H}_{2} \mathrm{O}_{2}$ always affected the $S$. latissima lamina in patches, and one could infer that the larger the lamina, the larger the chance that healthy, unaffected tissue is left post-exposure that could aid in lamina regeneration. Older S. latissima sporophytes have been shown to be more tolerant than juveniles to high light stress, and to recover faster after damage to the photosystem (Hanelt et al. 1997). It is therefore likely that older sporophytes are also more tolerant to $\mathrm{H}_{2} \mathrm{O}_{2}$ stress than juveniles, both due to physiology and lamina size. The position of the patch, i.e. a non-affected meristem, will most likely also increase chance of survival, as has been observed in relation to bryozoan cover on the lamina of $S$. latissima (pers. obs.). Both higher initial biomasses and unaffected meristems might have increased the endurance and led to survival of 2 of the plants in the $85 \mathrm{mg} \mathrm{l}^{-1}$ concentration.

\subsection{Effects of $\mathrm{H}_{2} \mathrm{O}_{2}$ on photosynthesis and carbon budget}

Our results demonstrate that the antioxidative system of $S$. latissima plants can cope with exogeneous exposure to low ( $\leq 17 \mathrm{mg} \mathrm{l}^{-1}$ ) concentrations of $\mathrm{H}_{2} \mathrm{O}_{2}$, most likely through scavenging before any significant oxidative stress and irreversible damage are caused. Exposure to high ( $\geq 85 \mathrm{mg} \mathrm{l}^{-1}$ ) concentrations, however, caused an immediate and dramatically reduced $P_{\text {MAX }}$ and $\alpha$, indicating that the oxidative stress was too high for the photosynthetic system to function. This can prevent plants from maintaining a positive carbon budget and consequently have no surplus carbon available for cell repair and growth. The response is comparable to that of $U$. rigida (Collén \& Pedersén 1996) post-exposure to a lower concentration (10.2 $\mathrm{mg} \mathrm{H}_{2} \mathrm{O}_{2} \mathrm{l}^{-1}$ ), and to $S$. latissima plants exposed to extreme temperature stress (Andersen et al. 2013). Dummermuth et al. (2003) studied antioxidative potentials of several species of seaweed by exposing them to different concentrations of $\mathrm{H}_{2} \mathrm{O}_{2}$. For an $\mathrm{H}_{2} \mathrm{O}_{2}$ concentration of $68 \mathrm{mg} \mathrm{l}^{-1}$, they found a 90 to $95 \%$ reduction in photosynthetic efficiency (in $F_{\mathrm{v}} / F_{\mathrm{m}}$ ) for the kelp species bladderlocks Alaria esculenta and arctic kelp Laminaria solidungula, equivalent to the $\alpha$-reduction we observed for $S$. latissima. 
After $15 \mathrm{~d}$, only 2 plants were left in the $85 \mathrm{mg} \mathrm{l}^{-1}$ concentration, and the following discussion on the prolonged impact should therefore be interpreted with care. Paler patches on the lamina were still visible on the plants at this time, indicating non-recovery in pigment concentration. Under low light, photosynthetic rate is limited by the rate of photochemical reactions (Steemann Nielsen 1975), which depends on light-harvesting pigments. Correlations between lower pigment concentration and lower $\alpha$ have previously been reported for S. latissima (Gerard 1988, Davison et al. 1991, Hanelt et al. 1997) as well as for higher plants (Pastori \& Trippi 1993). The still reduced $\alpha$ found for these plants may therefore have been caused by a prolonged effect on their pigment concentration. $P_{\text {MAX }}$ of these 2 plants was similar to that of the control plants, indicating recovered response to high light conditions.

The slow recovery of $\alpha$ prolongs the negative impact on both $I_{\mathrm{C}}$ and $I_{\mathrm{SAT}}$, and under natural light regimes, this could result in an overall reduced daily carbon fixation for S. latissima (Bruhn \& Gerard 1996). Firstly, by having a higher $I_{C}$, plants may be more susceptible to light limitation and more vulnerable to additional factors, such as shading by epiphytic growth, which could result in an imbalance of the plants' carbon budget (Andersen et al. 2013). Secondly, having a reduced $I_{\mathrm{SAT}}$ may prevent plants from taking advantage of occasional high light conditions. S. latissima inhabits the sublittoral, where the light conditions are often sub-saturating (Davison et al. 1991), and to be able to take advantage of any available light, it is important to maintain a viable carbon budget to support growth and reproduction. A reduced daily carbon fixation, in addition to a continuous loss of tissue, are possible causes for the lack of growth observed $15 \mathrm{~d}$ post-exposure for these 2 plants. Lack of growth may also have been affected by energy being diverted from growth due to the demand for repair (Roleda et al. 2007). The rate of carbon fixation might have also been too low for the plants to replace the lost pigments, preventing $\alpha$ and consequently $I_{\mathrm{C}}$ and $I_{\mathrm{SAT}}$ to recover. Based on the above-mentioned results, we propose that exposure to $85 \mathrm{mg} \mathrm{l}^{-1}$ is either lethal to juvenile $S$. latissima, or may have a prolonged negative effect on their physiology and carbon budget.

An increase in $R_{\mathrm{D}}$ is typically observed for algae during stress (Davison et al. 1991, Andersen et al. 2013), although impacted plants demonstrated a reduction in the present study, as was observed by Vega et al. (2006) for microalgae. A reduced $R_{\mathrm{D}}$ would be an advantage for the plant, as it would reduce carbon loss during dark periods (Davison et al. 1991). However, as $P_{\mathrm{MAX}}$ and $\alpha$ at this time indicate that the photosynthetic system was not only reduced, but barely functioning; it may be the same for respiration. The delayed effect on $R_{\mathrm{D}}$ compared to photosynthesis indicates that respiration is less sensitive to $\mathrm{H}_{2} \mathrm{O}_{2}$ and oxidative stress, as shown for $U$. rigida (Collén \& Pedersén 1996) and microalgae (Vega et al. 2006). $\mathrm{H}_{2} \mathrm{O}_{2}$ primarily targets and oxidizes enzymes of the Calvin cycle, such as fructose1,6-bisphosphatase (Asada 1992), enzymes that are essential for photosynthesis to take place, but not respiration. In addition, photosynthesis is reliant on chlorophyll as a catalyst, which has been shown to decrease with $\mathrm{H}_{2} \mathrm{O}_{2}$ exposure, whereas no catalyst is required for respiration (Campbell \& Reece 2002). It may be that $R_{\mathrm{D}}$ is not negatively affected until the photosystem is severely inhibited, hence no response is seen immediately post-exposure.

For the control plants, the values for $P_{\mathrm{MAX}}, \alpha$, and $R_{\mathrm{D}}$ were within the natural variation found for $S$. latissima in other studies (Davison et al. 1991, Borum et al. 2002, Andersen et al. 2013), indicating the method used to measure and calculate the parameters was suitable. Using photosynthetic performance as an indicator of physiological stress is a wellestablished method in the field of phycology (Dummermuth et al. 2003), and has been shown in this study to be suitable for studying the toxicity potentials of a chemical. The change in $P_{\text {MAX }}$ and $\alpha$ observed for the control plants after $15 \mathrm{~d}$ may have been due to different levels of environmental conditions in the laboratory compared to what the plants were adapted to in nature. Possible explanations include: lower water flow which could reduce the boundary layer and thus lead to a decreased gas exchange and accessibility to nutrients, lower nutrient levels as no medium was added to the seawater, and/or lower light conditions. However, this does not affect the reliability of the results in this study, as interpretative caution of the results has already been taken due to the low number of surviving plants in the high (85 $\mathrm{mg} \mathrm{H}_{2} \mathrm{O}_{2} \mathrm{l}^{-1}$ ) concentration.

\subsection{Potential effects on natural populations}

The dispersion models (Refseth et al. 2017, O. Samuelsen unpubl. data) offer a more complete picture of the spatial and temporal movements of the $\mathrm{H}_{2} \mathrm{O}_{2}$ plume compared to the field studies (i.e. by Andersen \& Hagen 2016, Fagereng 2016) and are hence considered more suitable for discussing the 
potential concentrations that $S$. latissima may be exposed to and the subsequent impacts. Simulations done by Refseth et al. (2017) on the dilution and spread of $\mathrm{H}_{2} \mathrm{O}_{2}$ in surface waters (0-3 m depth) predicted that areas within $1000 \mathrm{~m}$ of the emitting fish farm can experience concentrations almost twice as high as the concentration found in this study to cause $100 \%$ mortality. Within 2000 m, simulated concentrations were higher than the herein-determined $\mathrm{LC}_{90}$. The second dispersion model (O. Samuelsen unpubl. data) predicted a higher dilution rate of $\mathrm{H}_{2} \mathrm{O}_{2}$ and that the highest concentration of $\mathrm{H}_{2} \mathrm{O}_{2}$ within $5600 \mathrm{~m}$ post-emission would be lower than the current study's determined $\mathrm{LC}_{50}$, but still higher than the $\mathrm{EC}_{50}$ values for both $\alpha$ and $P_{\mathrm{MAX}}$. Both models thus indicate that exposure to $\mathrm{H}_{2} \mathrm{O}_{2}$ levels, that in the current study were found to negatively affect the photosynthesis of $S$. latissima, near farms are possible, while lethal exposures to $S$. latissima juveniles (within $2000 \mathrm{~m}$ ) are only predicted in the Refseth et al. (2017) model. Delousing operations usually involve multiple bath-treatments (1 net pen at a time), hence non-target species will most likely experience several $\mathrm{H}_{2} \mathrm{O}_{2}$ exposures over several days (Grefsrud et al. 2018), which may further decrease the $\mathrm{LC}_{50}$ and $\mathrm{EC}_{50}$ values, as reported for American lobster Homarus americanus (Burridge et al. 2000, 2008). Fish farms are generally located close to land or skerries, thus often overlapping with the distribution of $S$. latissima beds. Furthermore, the number of $\mathrm{H}_{2} \mathrm{O}_{2}$ prescriptions given to fish farms in 2016 was highest for the months January to March (Grefsrud et al. 2018), which overlaps with the recruitment period (October to March) for sugar kelp (Andersen et al. 2011, Andersen 2013). A high mortality or reduced photosynthesis of the local juvenile $S$. latissima population during the recruitment period could lead to reduced recruitment and affect the development of the demography of the adult $S$. latissima population. Furthermore, a reduced carbon budget may lead to lower fitness and make them more susceptible to other stressors (Wernberg et al. 2010), such as grazing, storm surges, or elevated temperatures, and in that way indirectly lead to mortality of local $S$. latissima beds.

Monitoring programmes are regularly executed at all aquaculture sites in Norway (MOM system: Ervik et al. 1997), to ensure environmental impacts are not exceeding set thresholds (Grefsrud et al. 2018). However, these do not include monitoring of marine flora, including kelp beds. The total proportion of local $S$. latissima beds that would experience lethal or sublethal concentrations of $\mathrm{H}_{2} \mathrm{O}_{2}$ from 1 emission will be highly dependent on the specific location of the farm, farm practice, treatment dose used, stratification of the water body, and current velocity and directions at the time of release (Andersen \& Hagen 2016, Refseth et al. 2017). There is thus a need for further field studies on the distribution of $\mathrm{H}_{2} \mathrm{O}_{2}$ in the vicinity of fish farms and well-boats during treatment operations to improve the models. Juvenile S. latissima may be a good indicator organism for future field studies of $\mathrm{H}_{2} \mathrm{O}_{2}$ distribution around farms, as they have demonstrated a high sensitivity, are easy to check for lethal effects (i.e. detachment of lamina), and are cost-effective to use as no maintenance is required after deployment. Nonetheless, based on the high sensitivity of $S$. latissima, the available dispersion models (Refseth et al. 2017, O. Samuelsen unpubl. data) and the importance of kelp forests in coastal ecosystems (Araújo et al. 2016), it is recommended that $\mathrm{H}_{2} \mathrm{O}_{2}$ use and emissions are taken under consideration in future risk assessments and monitoring programmes to ensure that these habitats remain healthy.

\subsection{Implications for $\mathrm{H}_{2} \mathrm{O}_{2}$ treatments at IMTA farms}

The increased interest for developing an industry in Norway based on $S$. latissima cultivation in integration with salmonid fish is evident from the rapid increase in permits awarded to the private sector over the last couple of years (Stévant et al. 2017). In 2017, a total amount of 135000 tons was harvested, with a value of 355000 NOK (Directorate of Fisheries Norway 2018a). Development of the cultivation technology to optimize yield and make the industry as cost-efficient as possible is currently the main focus (MACROSEA: www.sintef.no/projectweb/macrosea/, Stévant et al. 2017). Our results may have implications for the production yield of cultivated $S$. latissima next to fish farms, as on-site $\mathrm{H}_{2} \mathrm{O}_{2}$ emissions will most likely harm the cultured seaweeds, and it is therefore recommended that these emissions are considered. Sporophytes are commonly deployed in the sea when they are smaller than the ones exposed in this study. Emissions should therefore especially be avoided in the beginning of the sea-cultivation cycle to minimize chances of negative impacts on the yield.

This study clearly demonstrates that $S$. latissima is highly sensitive, with a high mortality found down to a concentration of $85 \mathrm{mg} \mathrm{H} \mathrm{H}_{2} \mathrm{O}^{-1}$ seawater. Moreover, a prolonged negative effect of the $\mathrm{H}_{2} \mathrm{O}_{2}$ exposure was demonstrated in surviving plants in the form of reduced photosynthetic efficiency and lack of new 
growth. The current extensive use and emission of $\mathrm{H}_{2} \mathrm{O}_{2}$ from fish farms in shallow areas is therefore likely to have negative impacts on the kelp community.

Acknowledgements. This study was financially supported by the Norwegian Research Council (Project no. 228871) and the Norwegian Ministry of Trade, Industry and Fisheries/Institute of Marine Research (Project no. 14907), Norway. We thank Jeroen Hendrik de Vree and Svein Rune Erga at the University of Bergen for valuable discussions on the experimental design and the 2 anonymous reviewers for comments that encouraged improvements of this manuscript.

\section{LITERATURE CITED}

Andersen GS (2013) Patterns of Saccharina latissima recruitment. PLOS ONE 8:e81092

Andersen PA, Hagen L (2016) Fortynningsstudier - hydrogenperoksid. Report 156-8-16. Aqua Kompetanse, Flatanger (in Norwegian). https://fhf.no/prosjektdetaljer/? projectNumber $=901226$

Andersen GS, Steen H, Christie H, Fredriksen S, Moy FE (2011) Seasonal patterns of sporophyte growth, fertility, fouling, and mortality of Saccharina latissima in Skagerrak, Norway: implications for forest recovery. J Mar Biol 2011:690375

Andersen GS, Pedersen MF, Nielsen SL (2013) Temperature acclimation and heat tolerance of photosynthesis in Norwegian Saccharina latissima (Laminariales, Phaeophyceae). J Phycol 49:689-700

Apostol I, Heinstein PF, Low PS (1989) Rapid stimulation of an oxidative burst during elicitation of cultured plant cells role in defense and signal transduction. Plant Physiol 90:109-116

Araújo R, Assis J, Aguillar R, Airoldi L and others (2016) Status, trends and drivers of kelp forests in Europe: an expert assessment. Biodivers Conserv 25:1319-1348

Asada K (1992) Ascorbate peroxidase-a hydrogen peroxide scavenging enzyme in plants. Physiol Plant 85: 235-241

Asada K, Takahashi M (1987) Production and scavenging of active oxygen in photosynthesis. In: Kyle DI, Osmond CB, Amtzen CJ (eds) Photoinhibition. Elsevier, Amsterdam, p 89-109

Barrington K, Chopin T, Robinson S (2009) Integrated multitrophic aquaculture (IMTA) in marine temperate waters. In: Soto D (ed) Integrated mariculture: a global review. FAO Fish Aquacult Tech Pap 529. FAO, Rome, p 7-46

* Bartsch I, Wiencke C, Bischof K, Buchholz CM and others (2008) The genus Laminaria sensu lato: recent insights and developments. Eur J Phycol 43:1-86

Benson BB, Krause D (1980) Isotopic fractionation of helium during solution: a probe for the liquid state. J Solution Chem 9:895-909

Benson BB, Krause D (1984) The concentration and isotopic fractionation of oxygen dissolved in freshwater and seawater in equilibrium with the atmosphere. Limnol Oceanogr 29:620-632

Bischof K, Rautenberger R (2012) Seaweed responses to environmental stress: reactive oxygen and antioxidative strategies. In: Wiencke C, Bischof K (eds) Seaweed biology. Springer-Verlag, Berlin, p 109-132
Bold HC, Wynne MJ (1978) Introduction to the algae: structure and reproduction. Prentice-Hall, Englewood Cliffs, NJ

* Borum J, Pedersen M, Krause-Jensen D, Christensen P, Nielsen K (2002) Biomass, photosynthesis and growth of Laminaria saccharina in a high-arctic fjord, NE Greenland. Mar Biol 141:11-19

* Bruhn J, Gerard V (1996) Photoinhibition and recovery of the kelp Laminaria saccharina at optimal and superoptimal temperatures. Mar Biol 125:639-648

Bruno D, Raynard R (1994) Studies on the use of hydrogen peroxide as a method for the control of sea lice on Atlantic salmon. Aquacult Int 2:10-18

* Burridge L, Haya K, Waddy S, Wade J (2000) The lethality of anti-sea lice formulations Salmosan® (azamethiphos) and Excis ${ }^{\circledR}$ (cypermethrin) to stage IV and adult lobsters (Homarus americanus) during repeated short-term exposures. Aquaculture 182:27-35

Burridge L, Haya K, Waddy S (2008) The effect of repeated exposure to azamethiphos on survival and spawning in the American lobster (Homarus americanus). Ecotoxicol Environ Saf 69:411-415

* Burridge L, Weis JS, Cabello F, Pizarro J, Bostick K (2010) Chemical use in salmon aquaculture: a review of current practices and possible environmental effects. Aquaculture 306:7-23

Bustnes JO, Christie H, Lorentsen S-H (1997) Sjøfugl, tareskog og taretråling: en kunnskapsstatus. NINA Oppdragsmelding no. 472. Norsk institutt for naturforskning (NINA), Trondheim (in Norwegian with English summary)

Campbell NA, Reece JB (2002) Biology. Benjamin Cummings, San Francisco, CA

Charpy-Roubaud C, Sournia A (1990) The comparative estimation of phytoplanktonic, microphytobenthic and macrophytobenthic primary production in the oceans. Mar Microb Food Webs 4:31-57

Christie H, Jørgensen NM, Norderhaug KM, Waage-Nielsen E (2003) Species distribution and habitat exploitation of fauna associated with kelp (Laminaria hyperborea) along the Norwegian coast. J Mar Biol Assoc UK 83:687-699

Christie H, Norderhaug KM, Fredriksen S (2009) Macrophytes as habitat for fauna. Mar Ecol Prog Ser 396: 221-233

Collén J, Davison IR (1999) Stress tolerance and reactive oxygen metabolism in the intertidal red seaweeds Mastocarpus stellatus and Chondrus crispus. Plant Cell Environ 22:1143-1151

Collén J, Pedersén M (1996) Production, scavenging and toxicity of hydrogen peroxide in the green seaweed Ulva rigida. Eur J Phycol 31:265-271

* Davison IR (1991) Environmental effects on algal photosynthesis: temperature. J Phycol 27:2-8

* Davison IR, Greene RM, Podolak EJ (1991) Temperature acclimation of respiration and photosynthesis in the brown alga Laminaria saccharina. Mar Biol 110:449-454

*Directorate of Fisheries Norway (2018a) Statistics for aquaculture: algae. Directorate of Fisheries Norway, Bergen. www.fiskeridir.no/Akvakultur/Statistikk-akvakultur/ Akvakulturstatistikk-tidsserier/Alger (accessed on 5 July 2018)

* Directorate of Fisheries Norway (2018b) Statistics for aquaculture: Atlantic salmon and rainbow trout. Directorate of Fisheries Norway, Bergen. www.fiskeridir.no/English/ Aquaculture/Statistics/Atlantic-salmon-and-rainbow-trout (accessed on 15 March 2018) 
Dummermuth A, Karsten U, Fisch K, König G, Wiencke C (2003) Responses of marine macroalgae to hydrogenperoxide stress. J Exp Mar Biol Ecol 289:103-121

Ervik A, Hansen PK, Aure J, Stigebrandt A, Johannessen P, Jahnsen $\mathrm{T}$ (1997) Regulating the local environmental impact of intensive marine fish farming I. The concept of the MOM system (Modelling-Ongrowing fish farmsMonitoring). Aquaculture 158:85-94

European Communities (2003) European Union risk assessment report: hydrogen peroxide. Institute for Health and Consumer Protection, Ispra

Fagereng MB (2016) Bruk av hydrogenperoksid i oppdrettsanlegg; fortynningstudier og effekter på blomsterreke (Pandalus montagui). MSc thesis, University of Bergen. http://bora.uib.no/handle/1956/13008

Fredriksen S (2003) Food web studies in a Norwegian kelp forest based on stable isotope $\left(\delta^{13} \mathrm{C}\right.$ and $\left.\delta^{15} \mathrm{~N}\right)$ analysis. Mar Ecol Prog Ser 260:71-81

Gerard V (1988) Ecotypic differentiation in light-related traits of the kelp Laminaria saccharina. Mar Biol 97:25-36

Grefsrud ES, Glover K, Grøsvik BE, Husa V and others (eds) (2018) Risikorapport norsk fiskeoppdrett 2018. Fisken og havet, særnr. 1-2018. Havforskningsinstituttet, Bergen (in Norwegian). www.hi.no/publikasjoner/andre publikasjoner/risikovurdering_miljovirkninger_av_norsk_ fiskeoppdrett/nb-no

Handå A, Forbord S, Wang X, Broch OJ and others (2013) Seasonal- and depth-dependent growth of cultivated kelp (Saccharina latissima) in close proximity to salmon (Salmo salar) aquaculture in Norway. Aquaculture 414-415:191-201

Hanelt D, Wiencke C, Karsten U, Nultsch W (1997) Photoinhibition and recovery after high light stress in different developmental and life history stages of Laminaria saccharina (Phaeophyta). J Phycol 33:387-395

Henley WJ, Dunton KH (1997) Effects of nitrogen supply and continuous darkness on growth and photosynthesis of the arctic kelp Laminaria solidungula. Limnol Oceanogr 42:209-216

Kaiser WM (1979) Reversible inhibition of the calvin cycle and activation of oxidative pentose phosphate cycle in isolated intact chloroplasts by hydrogen peroxide. Planta 145:377-382

Moy FE, Christie H (2012) Large-scale shift from sugar kelp (Saccharina latissima) to ephemeral algae along the south and west coast of Norway. Mar Biol Res 8:309-321

Norderhaug K, Christie H, Fosså J, Fredriksen S (2005) Fishmacrofauna interactions in a kelp (Laminaria hyperborea) forest. J Mar Biol Assoc UK 85:1279-1286

Pastori G, Trippi V (1993) Antioxidative protection in a drought-resistant maize strain during leaf senescence. Physiol Plant 87:227-231

Petrell R, Tabrizi KM, Harrison P, Druehl L (1993) Mathematical model of Laminaria production near a British
Columbian salmon sea cage farm. J Appl Phycol 5:1-14

* Pinheiro J, Bates D, Debroy S, Sarkar D, R Core Team (2017) nlme: linear and nonlinear mixed effects models. $\mathrm{R}$ package, version 3.1-131. https:/CRAN.R-project.org/ package $=$ nlme

R Core Team (2017) R: a language and environment for statistical computing, version 3.3.1. R Foundation for Statistical Computing, Vienna

* Rastrick SPS, Whiteley NM (2011) Congeneric amphipods show differing abilities to maintain metabolic rates with latitude. Physiol Biochem Zool 84:154-165

* Refseth G, Sæther K, Drivdal M, Nøst OA and others (2017) Miljørisiko ved bruk av hydrogenperoksid. Økotoksikologisk vurdering og grenseverdi for effekt. Rapport 8200-1. AkvaPlan NIVA, Tromsø (in Norwegian). www. fhf.no/prosjektdetaljer/?projectNumber $=901249$

* Ritz C, Baty F, Streibig JC, Gerhard D (2015) Dose-response analysis using R. PLOS ONE 10:e0146021

Roleda MY, Wiencke C, Hanelt D, Bischof K (2007) Sensitivity of the early life stages of macroalgae from the northern hemisphere to ultraviolet radiation. Photochem Photobiol 83:851-862

Samuelsen OB, Lunestad BT, Farestveit E, Grefsrud ES and others (2014) Mortality and deformities in European lobster (Homarus gammarus) juveniles exposed to the antiparasitic drug teflubenzuron. Aquat Toxicol 149:8-15

* Southard GM (2005) Use of hydrogen peroxide as an algaecide for Prymnesium parvum. In: Barkoh A, Fries LT (eds) Management of Prymnesium parvum at Texas State fish hatcheries. Management Data Series No. 236, PWD RP T3200-1138 (1/06). Texas Parks and Wildlife Department, Austin, TX, p 35-38. https://tpwd.texas. gov/publications/pwdpubs/media/pwd_rp_t3200_1138_ chapter7.pdf

Steemann Nielsen E (1975) Marine photosynthesis: with special emphasis on the ecological aspects. Elsevier, Amsterdam

* Stévant P, Rebours C, Chapman A (2017) Seaweed aquaculture in Norway: recent industrial developments and future perspectives. Aquacult Int 25:1373-1390

*Van Geest JL, Burridge LE, Kidd KA (2014) The toxicity of the anti-sea lice pesticide AlphaMax ${ }^{\circledR}$ to the polychaete worm Nereis virens. Aquaculture 430:98-106

*Vega JM, Garbayo I, Domínguez MJ, Vigara J (2006) Effect of abiotic stress on photosynthesis and respiration in Chlamydomonas reinhardtii: induction of oxidative stress. Enzyme Microb Technol 40:163-167

* Wernberg T, Thomsen MS, Tuya F, Kendrick GA, Staehr PA, Toohey BD (2010) Decreasing resilience of kelp beds along a latitudinal temperature gradient: potential implications for a warmer future. Ecol Lett 13:685-694

Zuur AF, Ieno EN, Walker NJ, Saveliev AA, Smith GM (2009) Mixed effects models and extensions in ecology with R. Springer, New York, NY 
APPENDIX. Preliminary $\mathrm{H}_{2} \mathrm{O}_{2}$ dose-response study in juvenile Saccharina latissima plants $(\mathrm{n}=6)$. Plants were exposed for $1 \mathrm{~h}$ to different dilutions of the common bath-treatment dose used in net pens for treating salmon for sea-lice infestations. Visible effects were recorded over time, from $0 \mathrm{~h}$ to $7 \mathrm{~d}$ post-exposure: discoloured lamina (Dis), lamina covered in mucus (Muc), soft and flaccid lamina (Fla), no visible effects (NVE), lamina had disintegrated and detached from stipe (Dead)

\begin{tabular}{|lclccccc}
\hline $\begin{array}{l}\text { Concentration } \\
\left(\mathrm{mg} \mathrm{H}_{2} \mathrm{O}_{2} \mathrm{l}^{-1}\right)\end{array}$ & $\begin{array}{c}\text { Dilution of bath } \\
\text { treatment }(\%)\end{array}$ & $0 \mathrm{~h}$ & $8 \mathrm{~h}$ & $22 \mathrm{~h}$ & $2 \mathrm{~d}$ & $3 \mathrm{~d}$ & $6 \mathrm{~d}$ \\
\hline 1700 & 100 & NVE & & & & & - \\
1250 & 75 & NVE & NVE & Dis, Muc Dis, Muc, Fla Dis, Muc, Fla Dis, Muc, Fla Dead & - \\
850 & 50 & NVE & NVE & Dis, Muc Dis, Muc, Fla Dis, Muc, Fla Dis, Muc, Fla Dead \\
475 & 25 & NVE & NVE & Dis, Muc Dis, Muc, Fla Dis, Muc, Fla Dis, Muc, Fla Dead \\
170 & 10 & NVE & NVE & Dis, Muc Dis, Muc, Fla Dis, Muc, Fla Dis, Muc, Fla Dead \\
Control & Control & NVE & NVE & NVE & NVE & NVE & NVE \\
\end{tabular}

Editorial responsibility: Alejandro Buschmann, Puerto Montt, Chile
Submitted: February 26, 2018; Accepted: November 2, 2018 Proofs received from author(s): December 10, 2018 